\title{
LEVEL II SCOUR ANALYSIS FOR BRIDGE 37 (BARTTH00080037) on TOWN HIGHWAY 8, crossing the WILLOUGHBY RIVER, BARTON, VERMONT
}

U.S. Geological Survey Open-File Report 96-405

Prepared in cooperation with

VERMONT AGENCY OF TRANSPORTATION and

FEDERAL HIGHWAY ADMINISTRATION 


\section{LEVEL II SCOUR ANALYSIS FOR BRIDGE 37 (BARTTH00080037) on TOWN HIGHWAY 8, crossing the WILLOUGHBY RIVER, BARTON, VERMONT}

By JOSEPH D. AYOTTE and ERICK M. BOEHMLER

U.S. Geological Survey Open-File Report 96-405

Prepared in cooperation with

VERMONT AGENCY OF TRANSPORTATION and

FEDERAL HIGHWAY ADMINISTRATION 


\title{
U.S. DEPARTMENT OF THE INTERIOR BRUCE BABBITT, Secretary
}

\author{
U.S. GEOLOGICAL SURVEY \\ Gordon P. Eaton, Director
}

For additional information write to:

District Chief

U.S. Geological Survey 361 Commerce Way

Pembroke, NH 03275-3718
Copies of this report may be purchased from:

U.S. Geological Survey Earth Science Information Center Open-File Reports Section Box 25286, MS 517 Federal Center

Denver, CO 80225 


\section{CONTENTS}

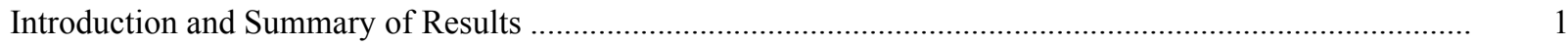

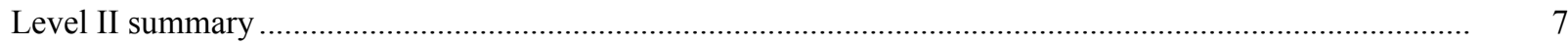

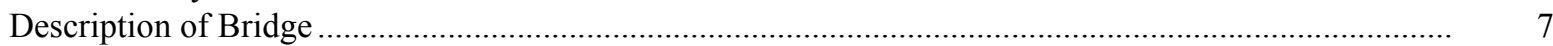

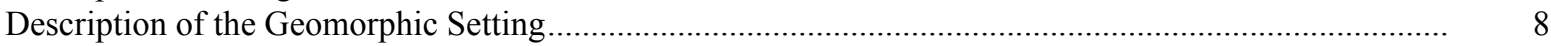

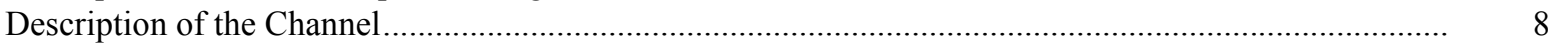

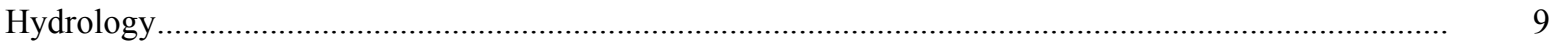

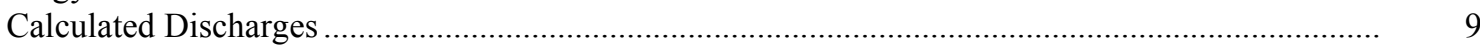

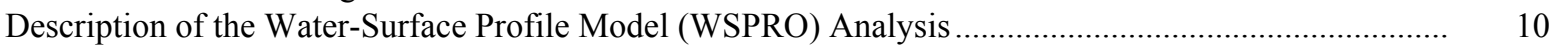

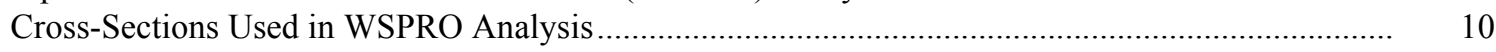

Data and Assumptions Used in WSPRO Model ...................................................................... 11

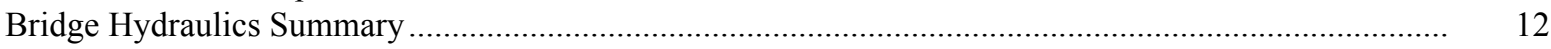

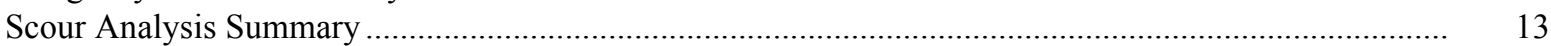

Special Conditions or Assumptions Made in Scour Analysis ...................................................... 13

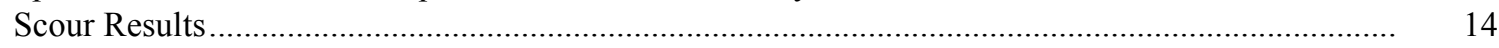

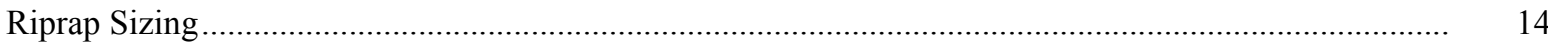

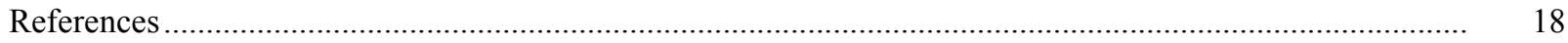

Appendixes:

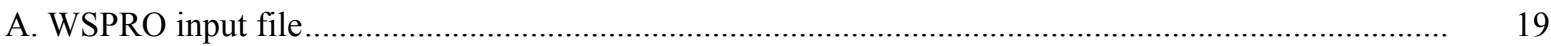

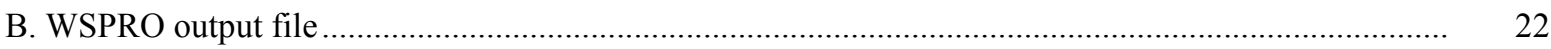

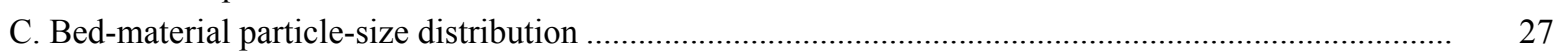

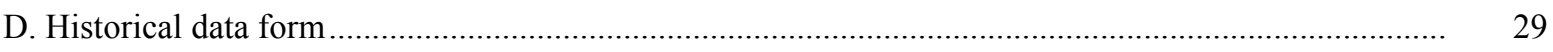

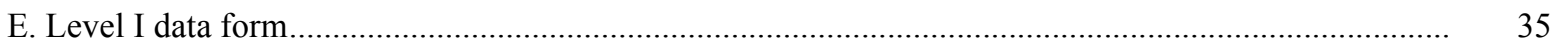

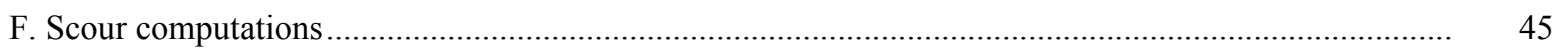

\section{FIGURES}

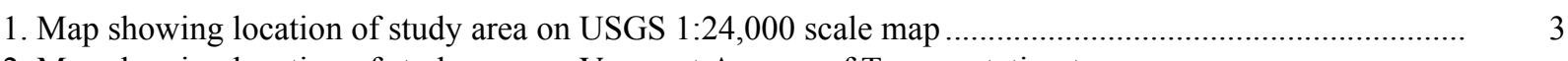

2. Map showing location of study area on Vermont Agency of Transportation town
highway map

3. Structure BARTTH00080037 viewed from upstream (October 20, 1994) .............................................. 5

4. Downstream channel viewed from structure BARTTH00080037 (October 20, 1994) ............................ 5

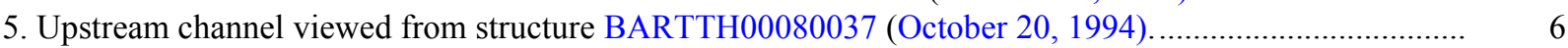

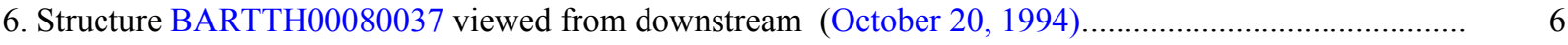

7. Water-surface profiles for the 100- and 500-year discharges at structure

BARTTH00080037 on Town Highway 8, crossing Willoughby River,

Barton, Vermont. 5

6

6

8. Scour elevations for the 100- and 500-year discharges at structure

BARTTH00080037 on Town Highway 8, crossing Willoughby River,

Barton, Vermont......

\section{TABLES}

1. Remaining footing/pile depth at abutments for the 100-year discharge at structure

BARTTH00080037 on Town Highway 8, crossing Willoughby River,

Barton, Vermont.

2. Remaining footing/pile depth at abutments for the 500-year discharge at structure

BARTTH00080037 on Town Highway 8, crossing Willoughby River,

Barton, Vermont. 


\begin{tabular}{|c|c|c|}
\hline Multiply & By & To obtain \\
\hline \multicolumn{3}{|c|}{ Length } \\
\hline inch (in.) & 25.4 & millimeter (mm) \\
\hline foot $(\mathrm{ft})$ & 0.3048 & meter $(\mathrm{m})$ \\
\hline mile (mi) & 1.609 & kilometer (km) \\
\hline \multicolumn{3}{|c|}{ Slope } \\
\hline foot per mile ( $\mathrm{ft} / \mathrm{mi})$ & 0.1894 & meter per kilometer $(\mathrm{m} / \mathrm{km})$ \\
\hline \multicolumn{3}{|c|}{ Area } \\
\hline square mile $\left(\mathrm{mi}^{2}\right)$ & 2.590 & square kilometer $\left(\mathrm{km}^{2}\right)$ \\
\hline \multicolumn{3}{|c|}{ Volume } \\
\hline cubic foot $\left(\mathrm{ft}^{3}\right)$ & $\begin{array}{l}0.02832 \\
\text { Velocity and Flow }\end{array}$ & cubic meter $\left(\mathrm{m}^{3}\right)$ \\
\hline foot per second (ft/s) & 0.3048 & meter per second $(\mathrm{m} / \mathrm{s})$ \\
\hline cubic foot per second $\left(\mathrm{ft}^{3} / \mathrm{s}\right)$ & 0.02832 & cubic meter per second $\left(\mathrm{m}^{3} / \mathrm{s}\right)$ \\
\hline $\begin{array}{l}\text { cubic foot per second per } \\
\text { square mile } \\
{\left[\left(\mathrm{ft}^{3} / \mathrm{s}\right) / \mathrm{mi}^{2}\right]}\end{array}$ & 0.01093 & $\begin{array}{l}\text { cubic meter per } \\
\text { second per square } \\
\text { kilometer }\left[\left(\mathrm{m}^{3} / \mathrm{s}\right) / \mathrm{km}^{2}\right]\end{array}$ \\
\hline
\end{tabular}

OTHER ABBREVIATIONS

$\begin{array}{lrlr}\mathrm{BF} & \text { bank full } & \text { LWW } & \text { left wingwall } \\ \mathrm{cfs} & \text { cubic feet per second } & \text { MC } & \text { main channel } \\ \mathrm{D}_{50} & \text { median diameter of bed material } & \text { RAB } & \text { right abutment } \\ \mathrm{DS} & \text { downstream } & \text { RABUT } & \text { face of right abutment } \\ \mathrm{elev} & \text { elevation } & \text { RB } & \text { right bank } \\ \mathrm{f} / \mathrm{p} & \text { flood plain } & \text { ROB } & \text { right overbank } \\ \mathrm{ft} & \text { square feet } & \text { RWW } & \text { right wingwall } \\ \mathrm{ft} / \mathrm{ft} & \text { feet per foot } & \text { TH } & \text { town highway } \\ \mathrm{JCT} & \text { junction } & \text { UB } & \text { under bridge } \\ \mathrm{LAB} & \text { left abutment } & \text { US } & \text { upstream } \\ \mathrm{LABUT} & \text { face of left abutment } & \text { USGS } & \text { United States Geological Survey } \\ \text { LB } & \text { left bank } & \text { VTAOT Vermont Agency of Transportation } \\ \text { LOB } & \text { left overbank } & \text { WSPRO } & \text { water-surface profile model }\end{array}$

In this report, the words "right" and "left" refer to directions that would be reported by an observer facing downstream. Sea level: In this report, "sea level" refers to the National Geodetic Vertical Datum of 1929-- a geodetic datum derived from a general adjustment of the first-order level nets of the United States and Canada, formerly called Sea Level Datum of 1929.

In the appendices, the above abbreviations may be combined. For example, USLB would represent upstream left bank. 


\title{
LEVEL II SCOUR ANALYSIS FOR BRIDGE 37 (BARTTH00080037) ON TOWN HIGHWAY 8, CROSSING THE WILLOUGHBY RIVER, BARTON, VERMONT
}

\author{
By Joseph D. Ayotte and Erick M. Boehmler
}

\section{INTRODUCTION AND SUMMARY OF RESULTS}

This report provides the results of a detailed Level II analysis of scour potential at structure BARTTH00080037 on town highway 8 crossing the Willoughby River, Barton, Vermont (figures 1-8). A Level II study is a basic engineering analysis of the site, including a quantitative analysis of stream stability and scour (U.S. Department of Transportation, 1993). Results of a Level I scour investigation also are included in Appendix E of this report. A Level I investigation provides a qualitative geomorphic characterization of the study site. Information on the bridge, gleaned from Vermont Agency of Transportation (VTAOT) files, was compiled prior to conducting Level I and Level II analyses and is found in Appendix D.

The site is in the New England Upland section of the New England physiographic province of north-central Vermont in the town of Barton. The $60.4-\mathrm{mi}^{2}$ drainage area is in a predominantly rural and forested basin. In the vicinity of the study site, the banks have sparse to moderate woody vegetation coverage.

In the study area, the Willoughby River is probably incised, has a sinuous channel with a slope of approximately $0.009 \mathrm{ft} / \mathrm{ft}$, an average channel top width of $108 \mathrm{ft}$ and an average channel depth of $6 \mathrm{ft}$. The predominant channel bed material is cobble $\left(\mathrm{D}_{50}\right.$ is $95.1 \mathrm{~mm}$ or $0.312 \mathrm{ft}$ ). The geomorphic assessment at the time of the Level I and Level II site visit on October 20, 1994, indicated that the reach was stable.

The town highway 8 crossing of the Willoughby River is a 96-ft-long, two-lane bridge consisting of one 94-foot steel-beam span (Vermont Agency of Transportation, written communication, August 4, 1994). The bridge is supported by vertical, concrete abutments with wingwalls. The channel is skewed approximately 15 degrees to the opening while the opening-skew-to-roadway is 10 degrees.

No scour was reported in the channel or along abutments or wingwalls during the Level I assessment. Type- 2 stone fill (less than 24 inches diameter) was reported at each abutment and all four wingwalls. Additional details describing conditions at the site are included in the Level II Summary and Appendices D and E. 
Scour depths and rock rip-rap sizes were computed using the general guidelines described in Hydraulic Engineering Circular 18 (Richardson and others, 1993). Scour depths were calculated assuming an infinite depth of erosive material and a homogeneous particle-size distribution. Data in appendix D (Vermont Agency of Transportation, written communication, August 4, 1994) indicate that the right abutment may be founded on or near marble bedrock which may limit scour depths. Bedrock was not detected by borings in the vicinity of the left abutment. The scour analysis results are presented in tables 1 and 2 and a graph of the scour depths is presented in figure 8.

Contraction scour for all modelled flows was $0 \mathrm{ft}$. Abutment scour ranged from 7.3 to 10.7 $\mathrm{ft}$ and the worst-case abutment scour occurred at the 500-year discharge. Additional information on scour depths and depths to armoring are included in the section titled "Scour Results". Scoured-streambed elevations, based on the calculated scour depths, are presented in tables 1 and 2. A cross-section of the scour computed at the bridge is presented in figure 8. Scour depths were calculated assuming an infinite depth of erosive material and a homogeneous particle-size distribution.

It is generally accepted that the Froehlich equation (abutment scour) gives "excessively conservative estimates of scour depths" (Richardson and others, 1993, p. 47). Usually, computed scour depths are evaluated in combination with other information including (but not limited to) historical performance during flood events, the geomorphic stability assessment, existing scour protection measures, and the results of the hydraulic analyses. Therefore, scour depths adopted by VTAOT may differ from the computed values documented herein. 


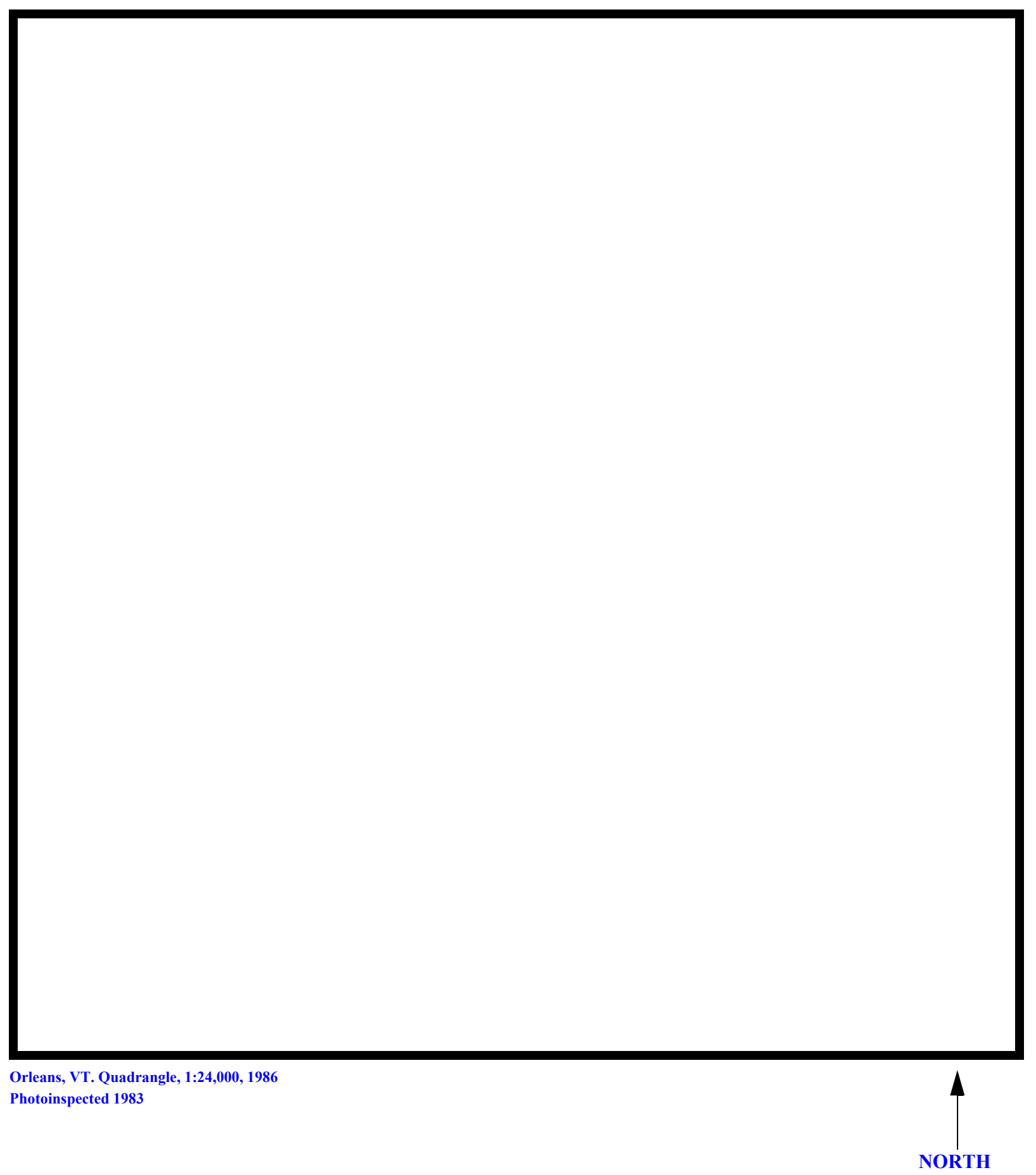

Figure 1. Location of study area on USGS 1:24,000 scale map. 
Figure 2. Location of study area on Vermont Agency of Transportation town highway map. 

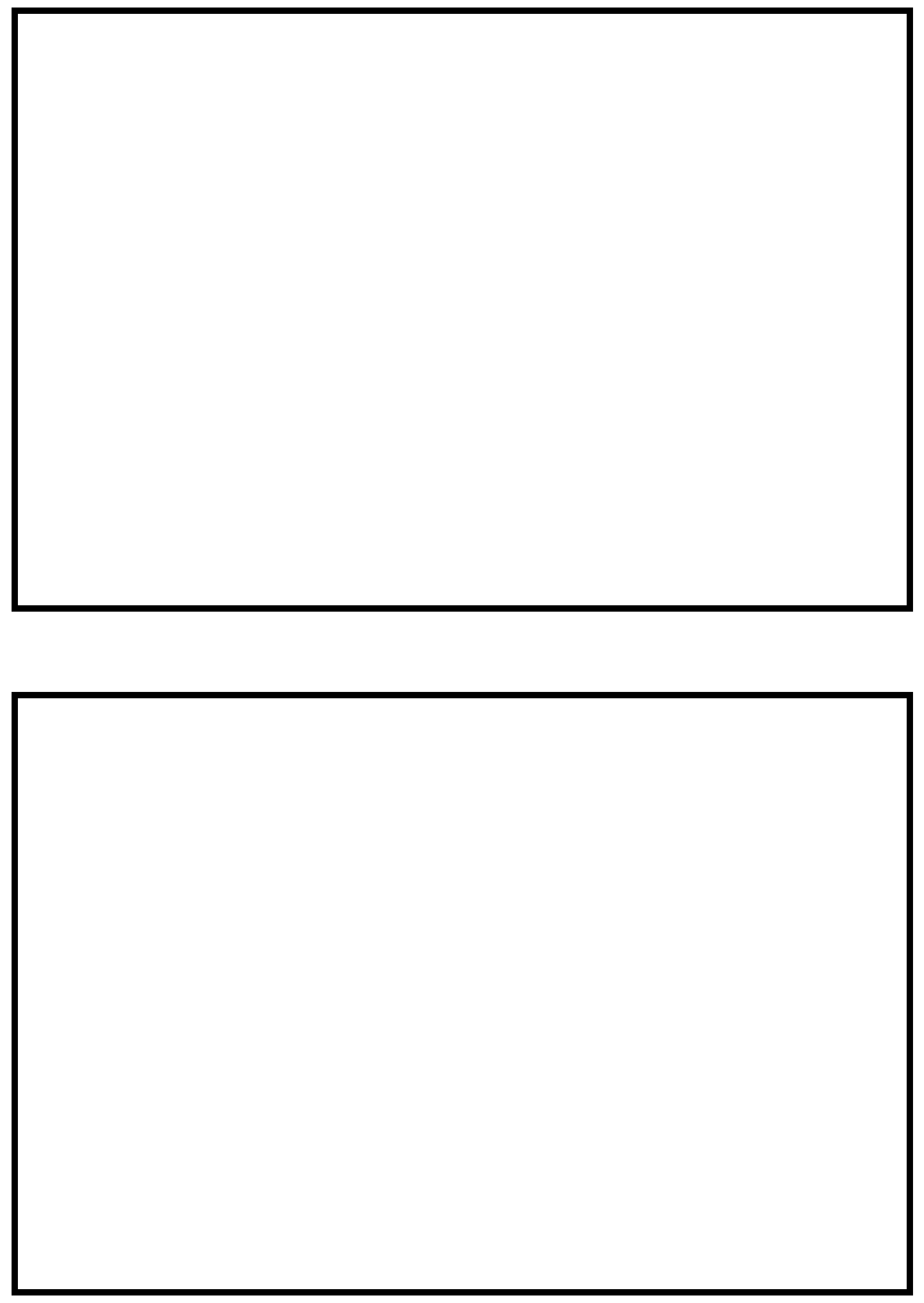

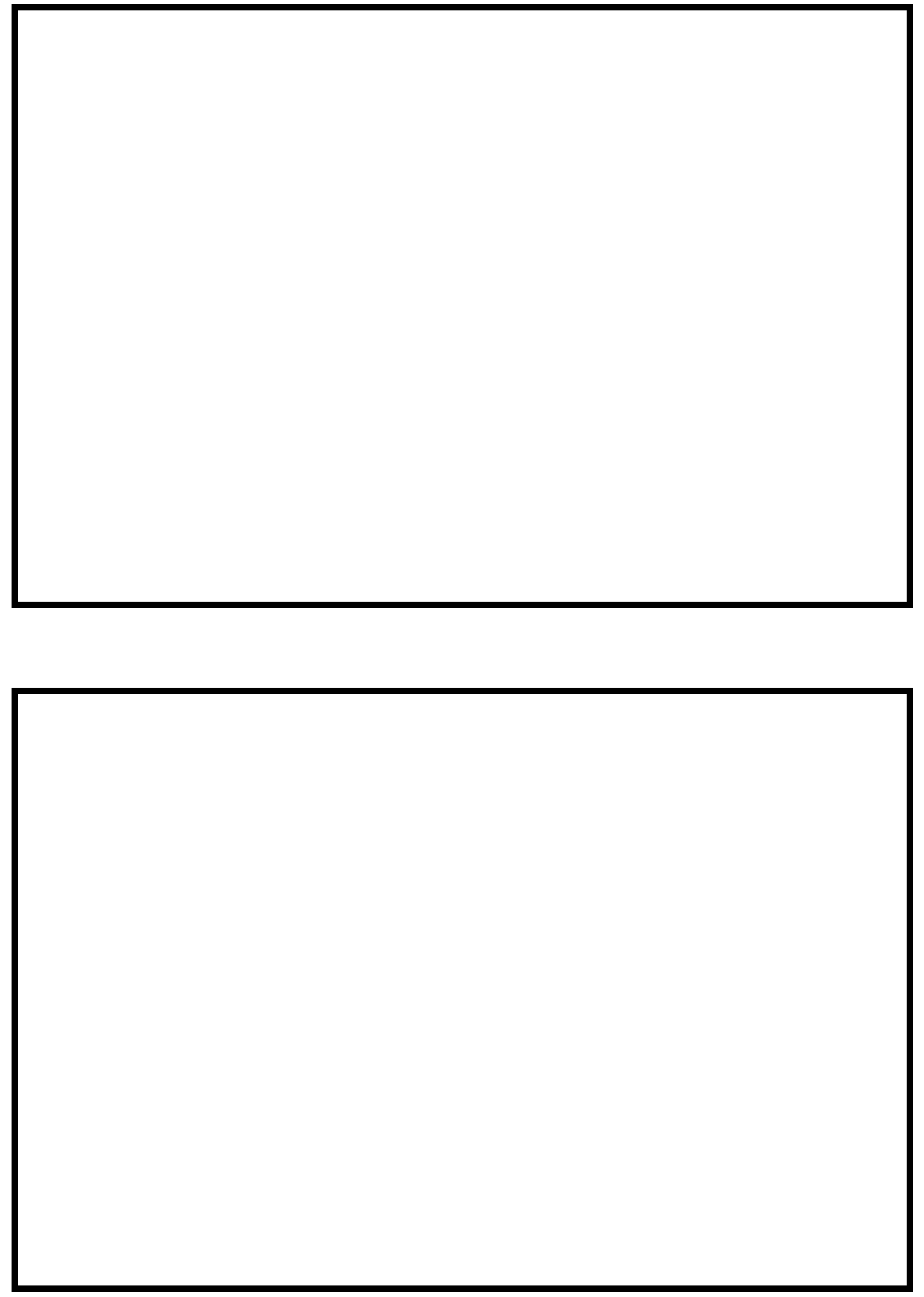


\section{LEVEL II SUMMARY}

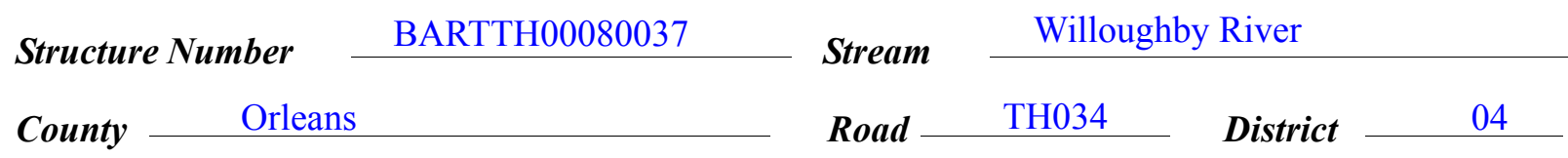

\section{Description of Bridge}

Bridge length $\frac{96}{4} \quad \boldsymbol{f t} \quad$ Bridge width $\stackrel{25.4}{f} \quad$ Max span length $\stackrel{94}{ } \boldsymbol{f t}$ Alignment of bridge to road (on curve or straight) Abutment type

Stone fill on abutment? Yes Embankment type Straight Danmintine of ataw a fill noto af insnortion Sloping $10 / 20 / 94$ Type-2, around both abutments and all four wingwalls, in good condition.

Abutments and wingwalls are concrete.

- . . . . . . . .

\section{$\mathrm{Y}$}

Is bridge skewed to flood flow according to Y Y survey?

Angle

There is a mild channel bend in the upstream reach.

Debris accumulation on bridge at time of Level I or Level II site visit:

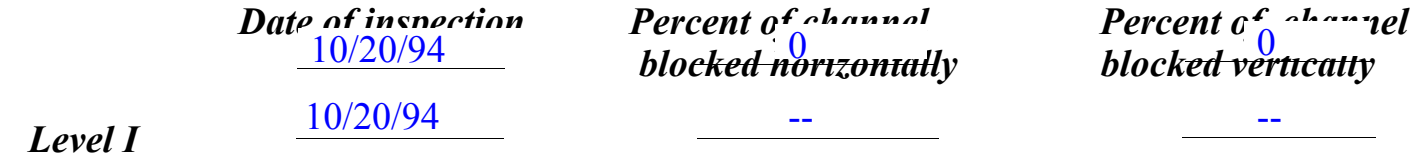

Level II

Moderate. There is a source of debris from trees leaning over the channel upstream.

Potential for debris

None as of 11/08/94.

Doscriho any, foaturos noar ar at tho hridos that mav, affoct flou, (includo ahsorvation dato) 


\section{Description of the Geomorphic Setting}

General topography The channel is located at a constriction in the Willoughby R near a major bend in the river.

Geomorphic conditions at bridge site: downstream (DS), upstream (US)

Date of inspection $\quad 10 / 20 / 94$

DS left: $\quad$ Narrow terrace to steep valley wall

DS right: $\quad$ Moderate flood plain to steep valley wall

US left: $\quad$ Narrow flood plain to steep valley wall

US right: $\quad$ Moderate flood plain to steep valley wall

\section{Description of the Channel}

\begin{tabular}{llll} 
Average top width & \multicolumn{10}{c}{ Average depth } & 6 & Gravel/Cobbles \\
\cline { 2 - 3 } & Cobbles
\end{tabular}

Predominant bed material Bank material Sinuous but stable

with semi-alluvial to non-alluvial channel boundaries and a narrow flood plain.

Vegetative co 1 Trees and brush and Vt. Rte $5 \ddot{58}$

DS left: $\quad$ Trees and brush

DS right: $\quad$ Trees and brush and Vt. Rte 58

US left: $\quad$ Trees and brush

US right: $\quad$ Y

Do banks appear stable? -

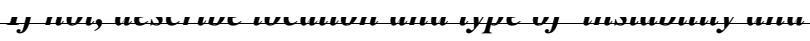

date of observatton.

11/8/95 none.

Describe any obstructions in channel and date of observation. 


\section{Hydrology}

Drainage area $\quad 60.4 \boldsymbol{m i}^{2}$

Percentage of drainage area in physiographic provinces: (approximate)

Physiographic province/section

New England / New England Upland
Percent of drainage area 100

Is drainage area considered rural or urban? Rural _ Describe any significant urbanization:

None. There are a couple houses on the upstream left overbank area beyond Vt. Rte. 58.

Is there a USGS gage on the stream of interest?

USGS gage description

USGS gage number

Gage drainage area $\quad \mathrm{mi}^{2}$ $\mathrm{N}$

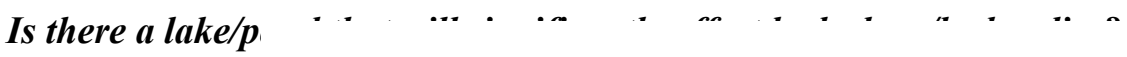

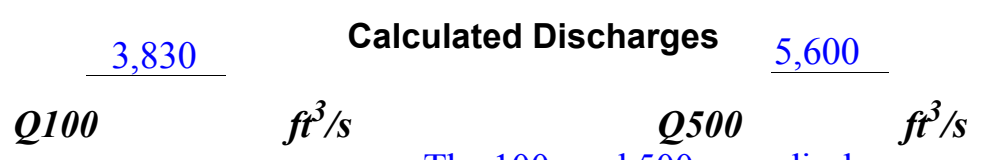

The 100- and 500-year discharges were selected

from a range of discharge values computed by several empirical relationships (Benson, 1962;

FHWA, 1983; Johnson and Tasker, 1974; Potter, 1957a\&b; Talbot, 1887). Because of the wide range of values resulting from the empirical relationships, a median value was selected for each discharge. 


\section{Description of the Water-Surface Profile Model (WSPRO) Analysis}

Datum for WSPRO analysis (USGS survey, sea level, VTAOT plans)

USGS survey

Datum tie between USGS survey and VTAOT plans

Add 308 to USGS survey to

obtain VTAOT plans' datum (to the nearest foot).

Description of reference marks used to determine USGS datum. $\quad$ RM1 is brass tablet on

top of the US end of the left abutment and wingwall joint (elev. $498.23 \mathrm{ft}$, arbitrary datum).

RM2 is a chiseled $\mathrm{X}$ on top of the DS end of the right abutment and wingwall joint (elev. 500.59

$\mathrm{ft}$, arbitrary datum).

Cross-Sections Used in WSPRO Analysis

${ }^{1}$ For location of cross-sections see plan-view sketch included with Level I field form, Appendix E.

For more detail on how cross-sections were developed see WSPRO input file. 


\section{Data and Assumptions Used in WSPRO Model}

Hydraulic analyses of the reach were done by use of the Federal Highway Administration's WSPRO step-backwater computer program (Shearman and others, 1986, and Shearman, 1990). The analysis reported herein reflects conditions existing at the site at the time of the study. Furthermore, in the development of the model it was necessary to assume no accumulation of debris or ice at the site. Results of the hydraulic model are presented in the Bridge Hydraulic Summary, Appendix B, and figure 7.

Channel roughness factors (Manning's " $n$ ") used in the hydraulic model were estimated using field inspections at each cross section following the general guidelines described by Arcement and Schneider (1989). Final adjustments to the values were made during the modelling of the reach. Channel " $\mathrm{n}$ " values for the reach ranged from 0.054 to 0.056 , and overbank " $\mathrm{n}$ " values ranged from 0.025 to 0.100 .

Normal depth at the exit section (EXITX) was assumed as the starting water surface. This depth was computed by use of the slope-conveyance method outlined in the User's manual for WSPRO (Shearman, 1990). The slope used was $0.0085 \mathrm{ft} / \mathrm{ft}$ which was estimated from the slope between common EXITX and BRIDG cross section points.

The surveyed approach section (APTEM) was moved along the approach channel slope $(0.00513 \mathrm{ft} / \mathrm{ft})$ to establish the modelled approach section (APPRO), one bridge length upstream of the upstream face as recommended by Shearman and others (1986). This approach also provides a consistent method for determining scour variables. 


\section{Bridge Hydraulics Summary}

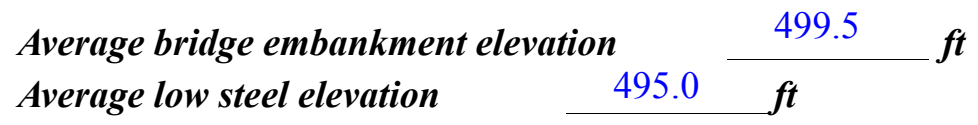

100-year discharge $\quad 3,830 \quad \mathrm{ft}^{3} / \mathrm{s}$

Water-surface elevation in bridge opening

$493.1 \boldsymbol{f t}$

Road overtopping? ___ N Discharge over road ___ ${ }^{--}$, is

\begin{tabular}{llll} 
Area of flow in bridge opening & $412 \quad \boldsymbol{f t}^{\mathbf{2}}$ \\
\cline { 2 - 3 } Average velocity in bridge opening & 9.3 & $\boldsymbol{f t} / \mathrm{s}$
\end{tabular}

Maximum WSPRO tube velocity at bridge $11.3 \mathrm{tt} / \mathrm{s}$

Water-surface elevation at Approach section with bridge 495.2

Water-surface elevation at Approach section without bridge $\quad 494.4$

Amount of backwater caused by bridge $\quad 0.8$ it

500-year discharge $\quad 5,600 \quad \mathrm{ft}^{3} / \mathrm{s}$

Water-surface elevation in bridge opening

$495.8 \boldsymbol{f t}$

Road overtopping? ___ N Discharge over road ___

\begin{tabular}{llll} 
Area of flow in bridge opening & 579 & $\boldsymbol{f t}^{\mathbf{2}}$ & \\
\cline { 2 - 4 } Average velocity in bridge opening & & 9.7 & $\mathrm{ft} / \mathrm{s}$
\end{tabular}

Maximum WSPRO tube velocity at bridge 11.1 _s

Water-surface elevation at Approach section with bridge 498.3

Water-surface elevation at Approach section without bridge $\quad 495.6$

Amount of backwater caused by bridge 2.7 .

Incipient overtopping discharge ___ -- $\mathrm{ft}^{3} / \mathrm{s}$

Water-surface elevation in bridge opening it

Area of flow in bridge opening $f t^{2}$

Average velocity in bridge opening $f t / s$

Maximum WSPRO tube velocity at bridge $f t / s$

Water-surface elevation at Approach section with bridge

Water-surface elevation at Approach section without bridge Amount of backwater caused by bridge it 


\section{Scour Analysis Summary}

\section{Special Conditions or Assumptions Made in Scour Analysis}

Scour depths were computed using the general guidelines described in Hydraulic Engineering Circular 18 (Richardson and others, 1993). Scour depths were calculated assuming an infinite depth of erosive material and a homogeneous particle-size distribution. The results of the scour analysis are presented in tables 1 and 2 and a graph of the scour depths is presented in figure 8 .

The 500-year discharge resulted in unsubmerged orifice flow. Contraction socur at bridges with orifice flow is best estimated by use of the Chang pressure-flow scour equation (oral communication, J. Sterling Jones, October 4, 1996). Therefore, contraction scour for the 500-year discharge was computed by use of the Chang equation (Richardson and others, 1995, p. 145-146). Contraction scour was computed by use of the clear-water contraction scour equation (Richardson and others, 1993, p. 35, equation 18) for the 100-year discharge. For contraction scour computations using the Laursen's equation, the average depth in the contracted section (AREA/TOPWIDTH) is subtracted from the depth of flow computed by the scour equation (Y2) to determine the actual amount of scour. The results of Laursen's clear-water contraction scour for the 500-year event were also computed and can be found in appendix F. In this case, neither discharge resulted in reportable contraction scour.

Abutment scour for the both abutments at all modelled discharges was computed by use of the Froehlich equation (Richardson and others, 1993, p. 49, equation 24). Variables for the Froehlich equation include the Froude number of the flow approaching the embankments, the length of the embankment blocking flow, and the depth of flow approaching the embankment less any roadway overtopping. 


\section{Scour Results}

100-yr discharge 500-yr discharge

Incipient

Contraction scour:

(Scour depths in feet)

Main channel

Live-bed scour

Clear-water scour

Depth to armoring

Left overbank

Right overbank

Local scour:

Abutment scour

8.0

10.3

-- 7.3

Left abutment

$10.7-$

Right abutment

Pier scour

Pier 1

Pier 2
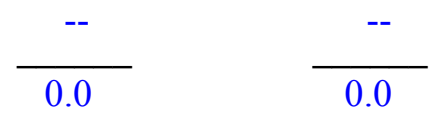

$3.1^{-}$

overtopping

discharge
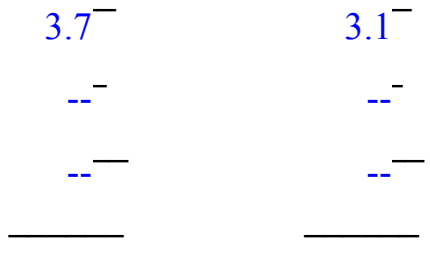

Pier 3

\section{Riprap Sizing}

Abutments:

Left abutment

Right abutment

Piers:

Pier 1

Pier 2

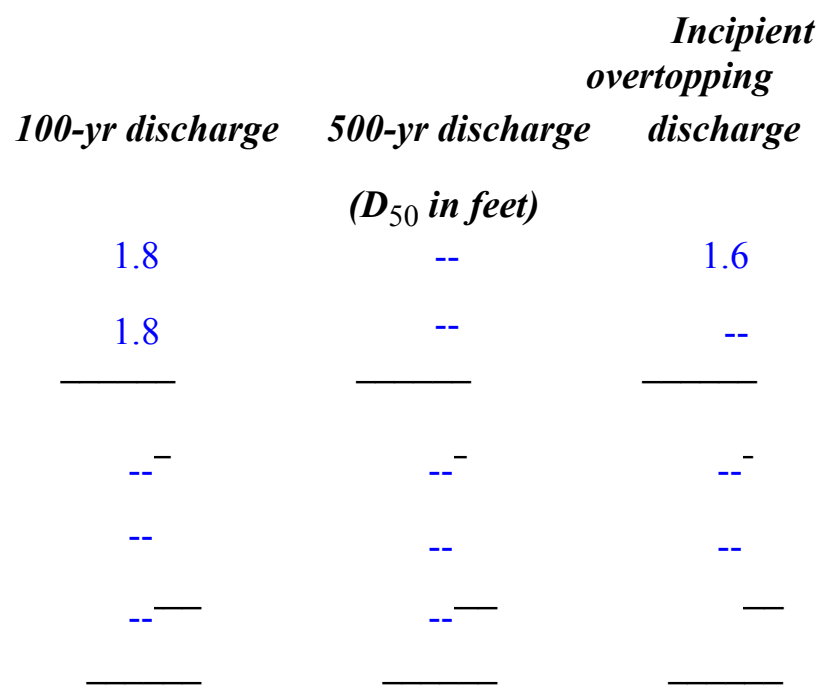




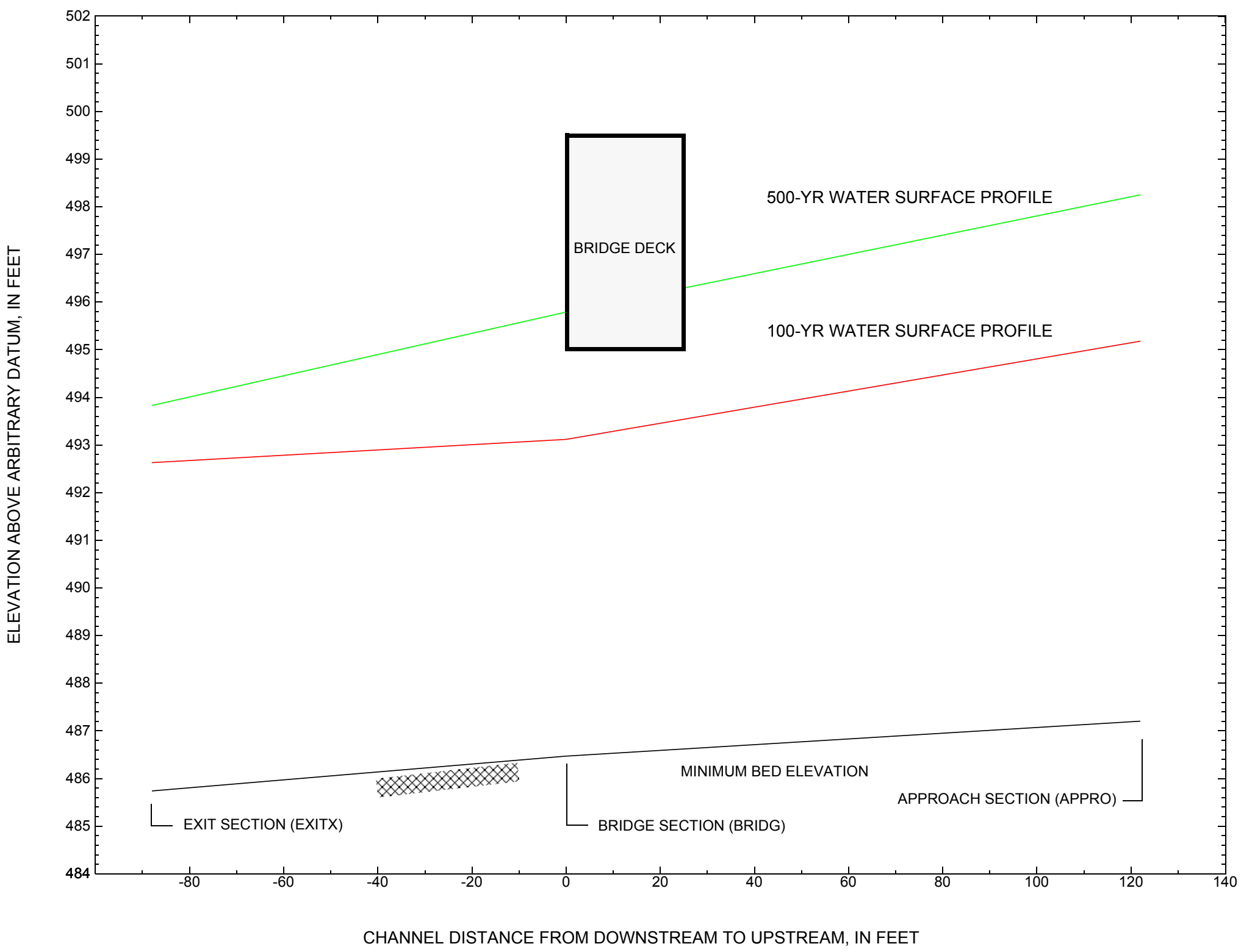

Figure 7. Water-surface profiles for the 100- and 500-yr discharges at structure BARTTH00080037 on town highway 8, crossing Willoughby River, Barton, Vermont. 


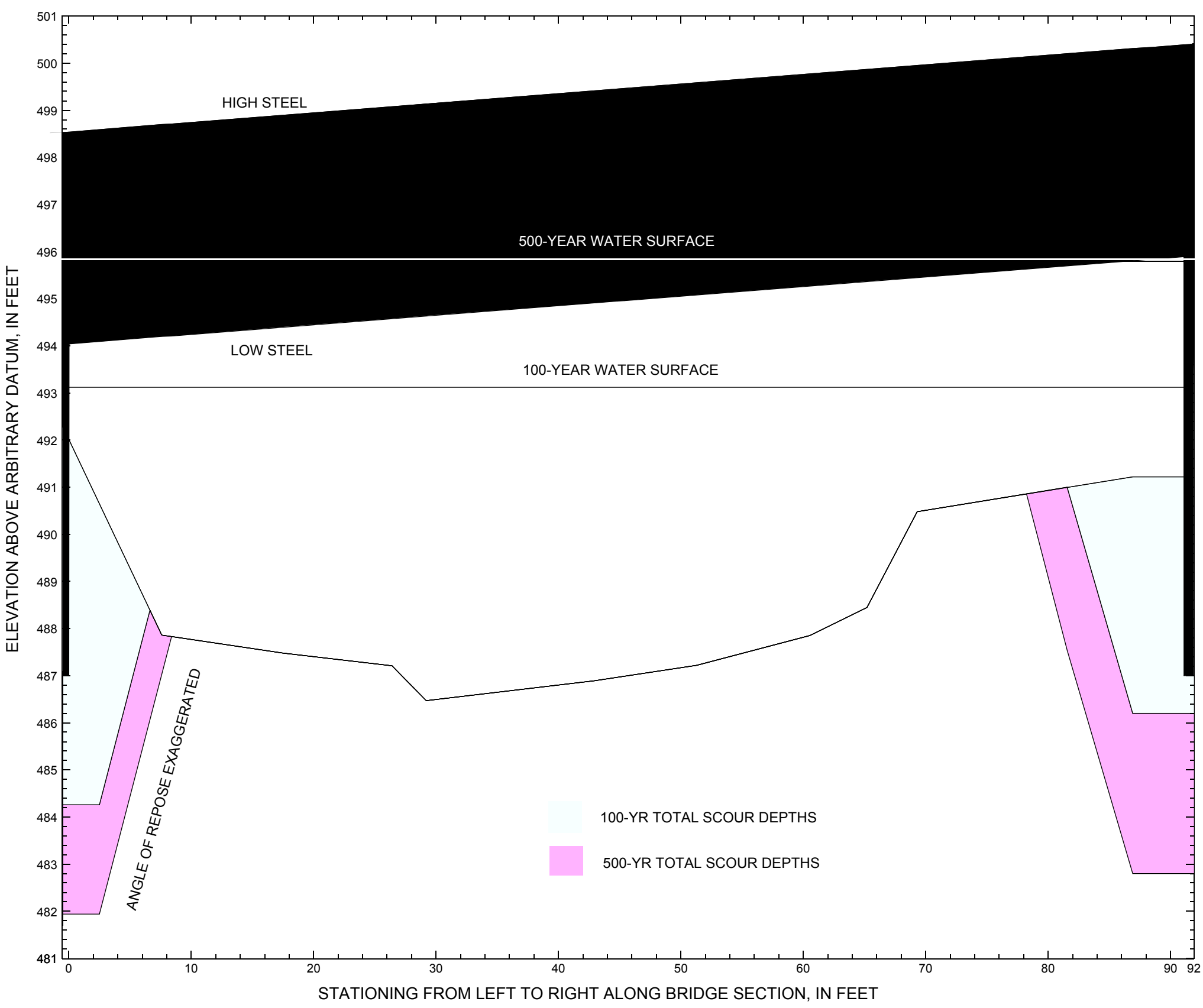

Figure 8. Scour elevations for the 100-yr and 500-yr discharges at structure BARTTH00080037 on town highway 8, crossing Willoughby River, Barton, Vermont. 
Table 1. Remaining footing/pile depth at abutments for the 100-year discharge at structure BARTTH00080037 on Town Highway 8, crossing Willoughby River, Barton, Vermont.

[VTAOT, Vermont Agency of Transportation; --,no data]

\begin{tabular}{|c|c|c|c|c|c|c|c|c|c|c|c|}
\hline Description & Station $^{1}$ & $\begin{array}{l}\text { VTAOT } \\
\text { minimum } \\
\text { low-chord } \\
\text { elevation } \\
\text { (feet) }\end{array}$ & $\begin{array}{l}\text { Surveyed } \\
\text { minimum } \\
\text { low-chord } \\
\text { elevation }{ }^{2} \\
\text { (feet) }\end{array}$ & $\begin{array}{l}\text { Bottom of } \\
\text { footing } \\
\text { elevation } \\
\text { (feet) }\end{array}$ & $\begin{array}{l}\text { Channel } \\
\text { elevation at } \\
\text { abutment/ } \\
\text { pier }^{2} \\
\text { (feet) }\end{array}$ & $\begin{array}{l}\text { Contraction } \\
\text { scour depth } \\
\text { (feet) }\end{array}$ & $\begin{array}{l}\text { Abutment } \\
\text { scour } \\
\text { depth } \\
\text { (feet) }\end{array}$ & $\begin{array}{l}\text { Pier } \\
\text { scour } \\
\text { depth } \\
\text { (feet) }\end{array}$ & $\begin{array}{l}\text { Depth of } \\
\text { total scour } \\
\text { (feet) }\end{array}$ & $\begin{array}{c}\text { Elevation of } \\
\text { scour }^{2} \\
\text { (feet) }\end{array}$ & $\begin{array}{c}\text { Remaining } \\
\text { footing/pile } \\
\text { depth } \\
\text { (feet) }\end{array}$ \\
\hline \multicolumn{12}{|c|}{100 -yr. discharge is 3,830 cubic-feet per second } \\
\hline Left abutment & 0.0 & 802.3 & 494.0 & 487 & 492.3 & 0.0 & 8.0 & -- & 8.0 & 484.3 & -3 \\
\hline Right abutment & 91.4 & 804.2 & 496.0 & 487 & 493.5 & 0.0 & 7.3 & -- & 7.3 & 486.2 & -1 \\
\hline
\end{tabular}

1. Measured along the face of the most constricting side of the bridge.

2. Arbitrary datum for this study.

Table 2. Remaining footing/pile depth at abutments for the 500-year discharge at structure BARTTH00080037 on Town Highway 8, crossing Willoughby River, Barton, Vermont.

[VTAOT, Vermont Agency of Transportation; --, no data]

\begin{tabular}{|c|c|c|c|c|c|c|c|c|c|c|c|}
\hline Description & Station ${ }^{1}$ & $\begin{array}{l}\text { VTAOT } \\
\text { minimum } \\
\text { low-chord } \\
\text { elevation } \\
\text { (feet) }\end{array}$ & $\begin{array}{l}\text { Surveyed } \\
\text { minimum } \\
\text { low-chord } \\
\text { elevation } \\
\quad \text { (feet) }\end{array}$ & $\begin{array}{l}\text { Bottom of } \\
\text { footing } \\
\text { elevation } \\
\text { (feet) }\end{array}$ & $\begin{array}{c}\text { Channel } \\
\text { elevation at } \\
\text { abutment/ } \\
\text { pier }^{2} \\
\text { (feet) }\end{array}$ & $\begin{array}{c}\text { Contraction } \\
\text { scour depth } \\
\text { (feet) }\end{array}$ & $\begin{array}{c}\text { Abutment } \\
\text { scour } \\
\text { depth } \\
\text { (feet) }\end{array}$ & $\begin{array}{l}\text { Pier } \\
\text { scour } \\
\text { depth } \\
\text { (feet) }\end{array}$ & $\begin{array}{l}\text { Depth of } \\
\text { total scour } \\
\text { (feet) }\end{array}$ & $\begin{array}{c}\text { Elevation of } \\
\text { scour }^{2} \\
\text { (feet) }\end{array}$ & $\begin{array}{c}\text { Remaining } \\
\text { footing/pile } \\
\text { depth } \\
\text { (feet) }\end{array}$ \\
\hline \multicolumn{12}{|c|}{ 500-yr. discharge is 5,600 cubic-feet per second } \\
\hline Left abutment & 0.0 & 802.3 & 494.0 & 487 & 492.3 & 0.0 & 10.3 & -- & 10.3 & 482.0 & -5 \\
\hline Right abutment & 91.4 & 804.2 & 496.0 & 487 & 493.5 & 0.0 & 10.7 & -- & 10.7 & 482.8 & -4 \\
\hline
\end{tabular}

1. Measured along the face of the most constricting side of the bridge.

2. Arbitrary datum for this study. 


\section{SELECTED REFERENCES}

Arcement, G.J., Jr., and Schneider, V.R., 1989, Guide for selecting Manning's roughness coefficients for natural channels and flood plains: U.S. Geological Survey Water-Supply Paper 2339, 38 p.

Barnes, H.H., Jr., 1967, Roughness characteristics of natural channels: U.S. Geological Survey Water-Supply Paper 1849, 213 p.

Benson, M. A., 1962, Factors Influencing the Occurrence of Floods in a Humid Region of Diverse Terrain: U.S. Geological Survey WaterSupply Paper 1580-B, 64 p.

Brown, S.A. and Clyde, E.S., 1989, Design of riprap revetment: Federal Highway Administration Hydraulic Engineering Circular No. 11, Publication FHWA-IP-89-016, 156 p.

Federal Highway Administration, 1983, Runoff estimates for small watersheds and development of sound design: Federal Highway Administration Report FHWA-RD-77-158

Froehlich, D.C., 1989, Local scour at bridge abutments in Ports, M.A., ed., Hydraulic Engineering--Proceedings of the 1989 National Conference on Hydraulic Engineering: New York, American Society of Civil Engineers, p. 13-18.

Hayes, D.C.,1993, Site selection and collection of bridge-scour data in Delaware, Maryland, and Virginia: U.S. Geological Survey WaterResources Investigation Report 93-4017, 23 p.

Johnson, C.G. and Tasker, G.D.,1974, Progress report on flood magnitude and frequency of Vermont streams: U.S. Geological Survey Open-File Report 74-130, 37 p.

Lagasse, P.F., Schall, J.D., Johnson, F., Richardson, E.V., Richardson, J.R., Chang, F., 1991, Stream Stability at Highway Structures: Federal Highway Administration Hydraulic Engineering Circular No. 20, Publication FHWA-IP-90-014, 195 p.

Laursen, E.M., 1960, Scour at bridge crossings: Journal of the Hydraulics Division, American Society of Civil Engineers, v. 86, no. HY2, p. 39-53.

Potter, W. D., 1957a, Peak rates of runoff in the Adirondack, White Mountains, and Maine woods area, Bureau of Public Roads

Potter, W. D., 1957b, Peak rates of runoff in the New England Hill and Lowland area, Bureau of Public Roads

Richardson, E.V. and Davis, S.R., 1995, Evaluating scour at bridges: Federal Highway Administration Hydraulic Engineering Circular No. 18, Publication FHWA-IP-90-017, 204 p.

Richardson, E.V., Harrison, L.J., Richardson, J.R., and Davis, S.R., 1993, Evaluating scour at bridges: Federal Highway Administration Hydraulic Engineering Circular No. 18, Publication FHWA-IP-90-017, 131 p.

Richardson, E.V., Simons, D.B., and Julien, P.Y., 1990, Highways in the river environment: Federal Highway Administration Publication FHWA-HI-90-016.

Ritter, D.F., 1984, Process Geomorphology: W.C. Brown Co., Debuque, Iowa, 603 p.

Shearman, J.O., 1990, User's manual for WSPRO--a computer model for water surface profile computations: Federal Highway Administration Publication FHWA-IP-89-027, 187 p.

Shearman, J.O., Kirby, W.H., Schneider, V.R., and Flippo, H.N., 1986, Bridge waterways analysis model; research report: Federal Highway Administration Publication FHWA-RD-86-108, 112 p.

Talbot, A.N., 1887, The determination of water-way for bridges and culverts.

U.S. Department of Transportation, 1993, Stream stability and scour at highway bridges, Participant Workbook: Federal Highway Administration Publication FHWA HI-91-011.

U.S. Geological Survey, 1986, Orleans, Vermont 7.5 Minute Series quadrangle map: U.S. Geological Survey Topographic Maps, Scale $1: 24,000$. 


\section{APPENDIX A: \\ WSPRO INPUT FILE}




\section{WSPRO INPUT FILE}

GR

GR

GR

$\mathrm{N}$

SA

\section{*}

*

BR

GR

GR

GR

GR

*

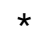

$\mathrm{CD}$

$\mathrm{N}$

*

*

$\mathrm{XR}$

GR

GR

GR

GR

*

$\mathrm{XT}$

GR

GR

GR

GR

*

AS

GT

$\mathrm{N}$

SA
U.S. Geological Survey WSPRO Input File bart037.wsp Hydraulic analysis for structure BARTTH00080037 Date: 08-APR-96 Barton br 37 on th 8 , crossing Willoughby R. JDA $3830.0 \quad 5600.0$

$0.0085 \quad 0.0085$

$\begin{array}{lllllllllllllllllllll}6 & 29 & 30 & 552 & 553 & 551 & 5 & 16 & 17 & 13 & 3 & * & 15 & 14 & 23 & 21 & 11 & 12 & 4 & 7 & 3\end{array}$
$-67.7,496.92$

$-18.4,491.28$

$32.3,485.87$

$93.2,489.47$

$17.5,487.48$

$51.3,487.22$

$86.9,491.22$

$69.3,490.48$

$0.0,494.01$

$65.2,488.45$

$91.4,495.96$

WWANGL WWWID

4.0

0.055

$\begin{array}{rrrr} & \text { SRD } & \text { EMBWID } & \text { IPAVE } \\ \text { RDWAY } & 15 & 25.4 & 1\end{array}$

$-190.6,513.42-168.1,503.90$

$0.0,498.34$

$-147.3,502.06$

$-93.9,498.20$

$46.0,499.28$

$93.8,500.60$

$95.7,500.42$

$1.4,498.48$

$232.4,507.75$

APTEM $101 \quad 0$.

$-193.6,508.82$

$-154.1,502.83$

$-64.4,498.30$

$-49.9,498.65$

$-5.4,495.87$

$7.0,488.40$

$15.6,487.38$

$26.5,487.09$

$57.3,489.80$

$38.1,487.13$

$50.4,487.38$

$53.4,487.99$

$124.2,501.02$ 
WSPRO INPUT FILE (continued)

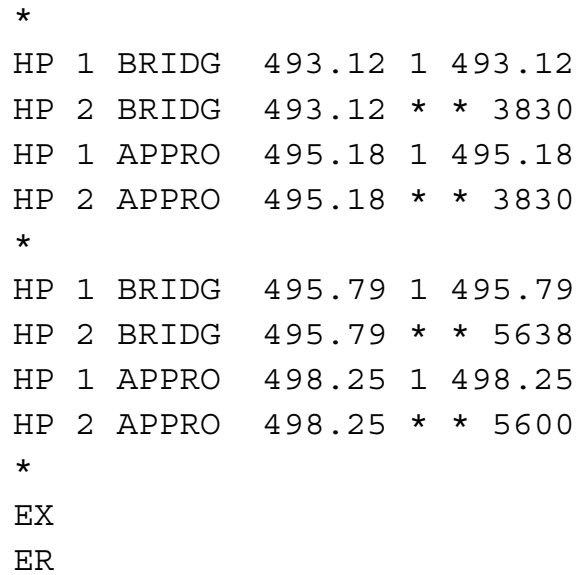




\section{APPENDIX B: \\ WSPRO OUTPUT FILE}




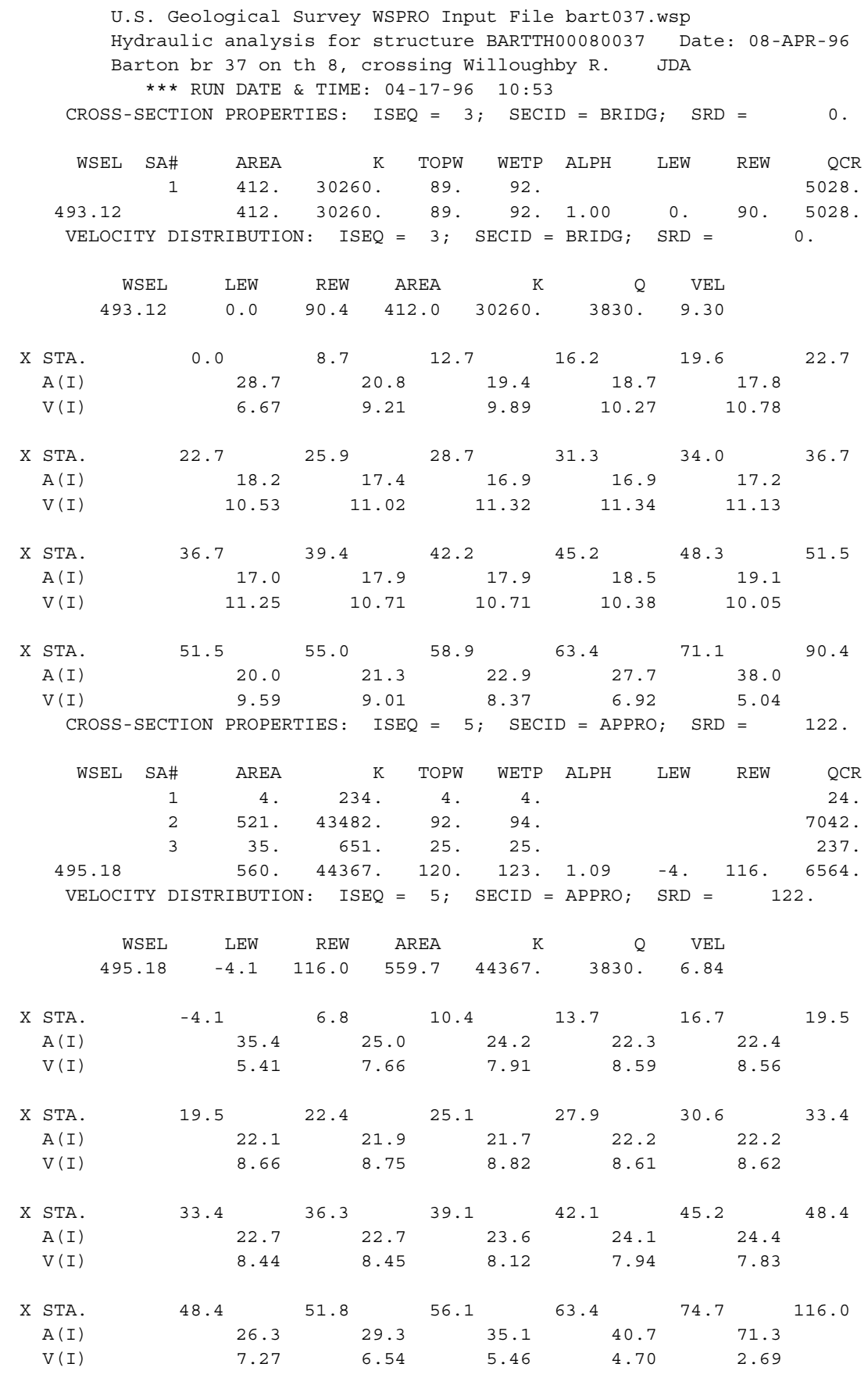


WSPRO OUTPUT FILE (continued)

\begin{tabular}{|c|c|c|c|c|c|c|c|c|c|c|c|c|}
\hline & CROSS-SEC & ECTION & PROPERT & TIES: & ISEQ & $2=3$ & $\mathrm{SECI}$ & $I D=B R I I$ & $D G$; & SRD & $=$ & 0. \\
\hline & WSEL SA & SA\# & AREA & & K & TOPW & WETP & ALPH & LEW & & REW & QCR \\
\hline & & 1 & 579. & 3434 & & 8. & 178. & & & & & 28231. \\
\hline & $\begin{array}{l}495.79 \\
\text { VELOCITY }\end{array}$ & $Y$ DISTR & $\begin{array}{c}579 . \\
\text { RIBUTION }\end{array}$ & $\begin{array}{r}3434 \\
N \quad \quad I S\end{array}$ & $\begin{array}{l}42 . \\
\mathrm{SEQ}=\end{array}$ & $\begin{array}{c}8 . \\
3 i\end{array}$ & $\begin{array}{c}178 . \\
\text { SECID }=\end{array}$ & $\begin{aligned} & 1.00 \\
= & \text { BRIDG; }\end{aligned}$ & $\begin{array}{r}0 . \\
\text { SRD }\end{array}$ & $\dot{D}=$ & 91. & $\begin{array}{l}28231 . \\
0 .\end{array}$ \\
\hline & WSEI & & LEW & REW & & REA & $\mathrm{K}$ & ( & Q & VEL & & \\
\hline & 495.79 & & 0.0 & 91.4 & 578 & B. 6 & 34342 . & 5638 & & 9.74 & & \\
\hline $\mathrm{X}$ & STA. & 0.0 & & 9.4 & & 14.2 & & 18.5 & & 22.6 & & 26.6 \\
\hline & $A(I)$ & & 41.1 & & 31.2 & & 29.3 & 28 & & & 28.2 & \\
\hline & $V(I)$ & & 6.85 & & 9.03 & & 9.61 & 9. & & & 9.99 & \\
\hline $\mathrm{x}$ & STA. & 26.6 & & 29.9 & & 33.1 & & 36.4 & & 39.6 & & 42.8 \\
\hline & $A(I)$ & & 26.0 & & 25.8 & & 25.9 & 25 & & & 25.4 & \\
\hline & $V(I)$ & & 10.83 & & 10.93 & & 10.88 & 11. & & & 11.09 & \\
\hline $\mathrm{X}$ & STA. & 42.8 & & 46.1 & & 49.3 & & 52.8 & & 56.2 & & 59.8 \\
\hline & $A(I)$ & & 25.8 & & 25.6 & & 26.6 & 26 & & & 26.8 & \\
\hline & $V(I)$ & & 10.93 & & 11.01 & & 10.60 & 10. & & & 10.53 & \\
\hline $\mathrm{X}$ & STA. & 59.8 & & 63.6 & & 68.5 & & 75.6 & & 83.2 & & 91.4 \\
\hline & $A(I)$ & & 27.6 & & 30.6 & & 35.2 & 35 & & & 31.4 & \\
\hline & $V(I)$ & & 10.22 & & 9.21 & & 8.01 & 7.8 & 87 & & 8.97 & \\
\hline & CROSS-SEC & ECTION & PROPERT & TIES: & ISEQ & $2=$ & SECII & $I D=A P P I$ & $\mathrm{RO} ;$ & SRD & $=$ & 122. \\
\hline & WSEL SA & SA\# & AREA & & $\mathrm{K}$ & TOPW & WETP & $\mathrm{ALPH}$ & LEW & & REW & QCR \\
\hline & & 1 & 60. & 454 & \pm 3. & 41. & 42. & & & & & 412 . \\
\hline & & 2 & 802 . & 8931 & 18. & 92. & 94. & & & & & 13461. \\
\hline & & 3 & 118. & 431 & 5. & 29. & 30. & & & & & 1343. \\
\hline & 498.25 & & 980. & 9817 & 76. & 162 . & 166. & 1.16 & -42 & & 120. & 12713. \\
\hline & VELOCITY & $Y$ DISTR & RIBUTION & $\mathrm{N}:$ IS & $\mathrm{SEQ}=$ & $5 ;$ & SECID $=$ & $=\mathrm{APPRO} ;$ & SRD & $D=$ & & 22 . \\
\hline & WSEI & & LEW & REW & & REA & $\mathrm{K}$ & 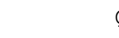 & 2 & VEL & & \\
\hline & 498.25 & & 41.8 & 120.2 & 979 & 9.6 & 98176. & 5600 & & 5.72 & & \\
\hline $\mathrm{x}$ & STA. & -41.8 & & 0.5 & & 7.2 & & 11.3 & & 15.2 & & 18.8 \\
\hline & $A(I)$ & & 65.5 & & 52.5 & & 40.7 & 40 & & & 38.9 & \\
\hline & $V(I)$ & & 4.27 & & 5.33 & & 6.87 & 6. & & & 7.19 & \\
\hline $\mathrm{x}$ & STA. & 18.8 & & 22.3 & & 25.8 & & 29.2 & & 32.7 & & 36.2 \\
\hline & $A(I)$ & & 38.5 & & 38.0 & & 37.7 & 38 & & & 38.5 & \\
\hline & $V(I)$ & & 7.28 & & 7.36 & & 7.44 & 7. & & & 7.28 & \\
\hline $\mathrm{X}$ & STA. & 36.2 & & 39.7 & & 43.3 & & 47.0 & & 50.7 & & 55.0 \\
\hline & $A(I)$ & & 39.0 & & 38.8 & & 40.4 & 40 & & & 43.4 & \\
\hline & $V(I)$ & & 7.17 & & 7.21 & & 6.93 & 6. & & & 6.45 & \\
\hline $\mathrm{x}$ & STA. & 55.0 & & 61.0 & & 68.3 & & 77.3 & & 89.4 & & 120.2 \\
\hline & $A(I)$ & & 50.1 & & 52.1 & & 56.5 & 62 & & & 126.4 & \\
\hline & $V(I)$ & & 5.59 & & 5.37 & & 4.95 & 4. & & & 2.22 & \\
\hline
\end{tabular}


WSPRO OUTPUT FILE (continued)

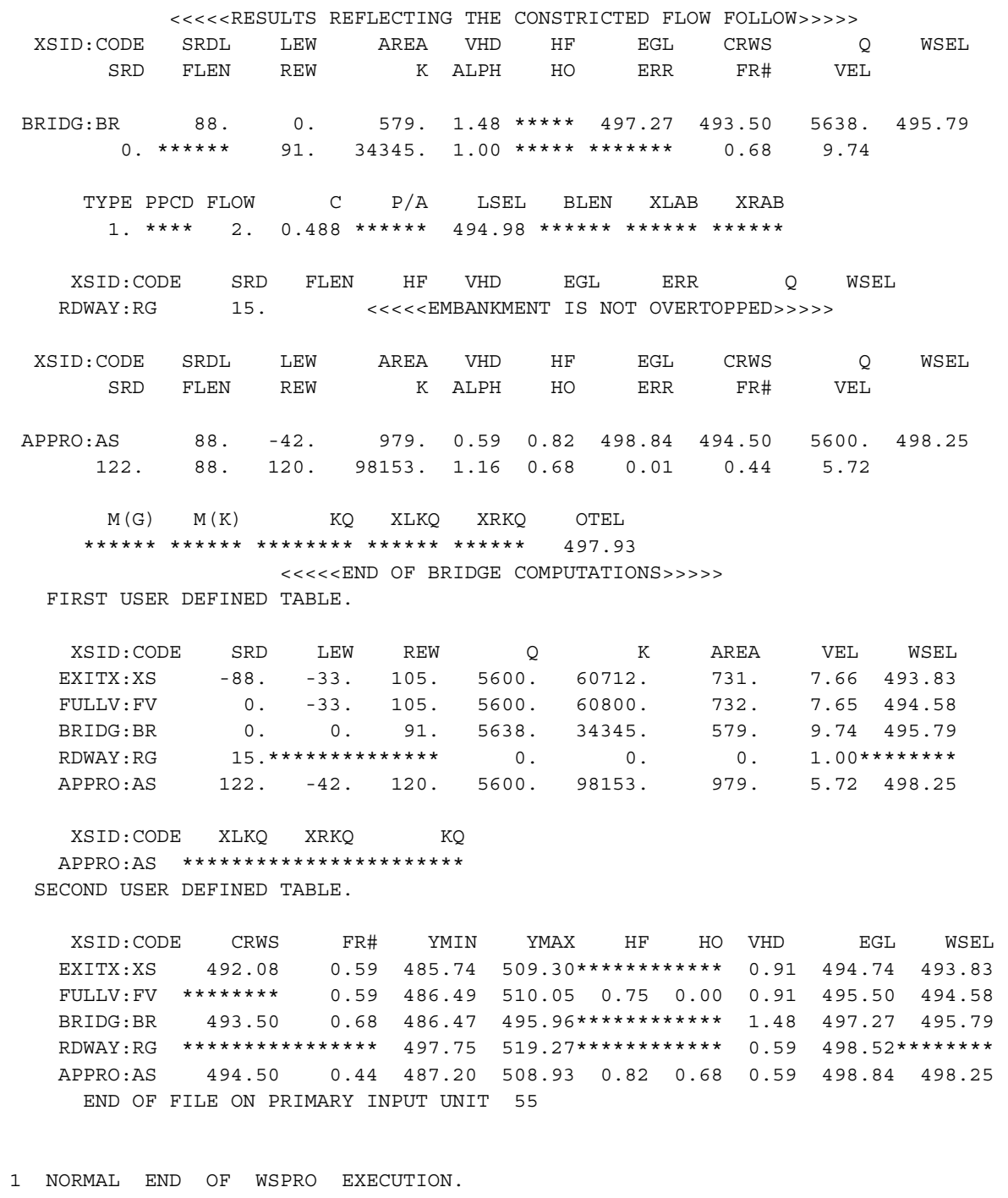




\section{APPENDIX C:}

\section{BED-MATERIAL PARTICAL-SIZE DISTRIBUTION}




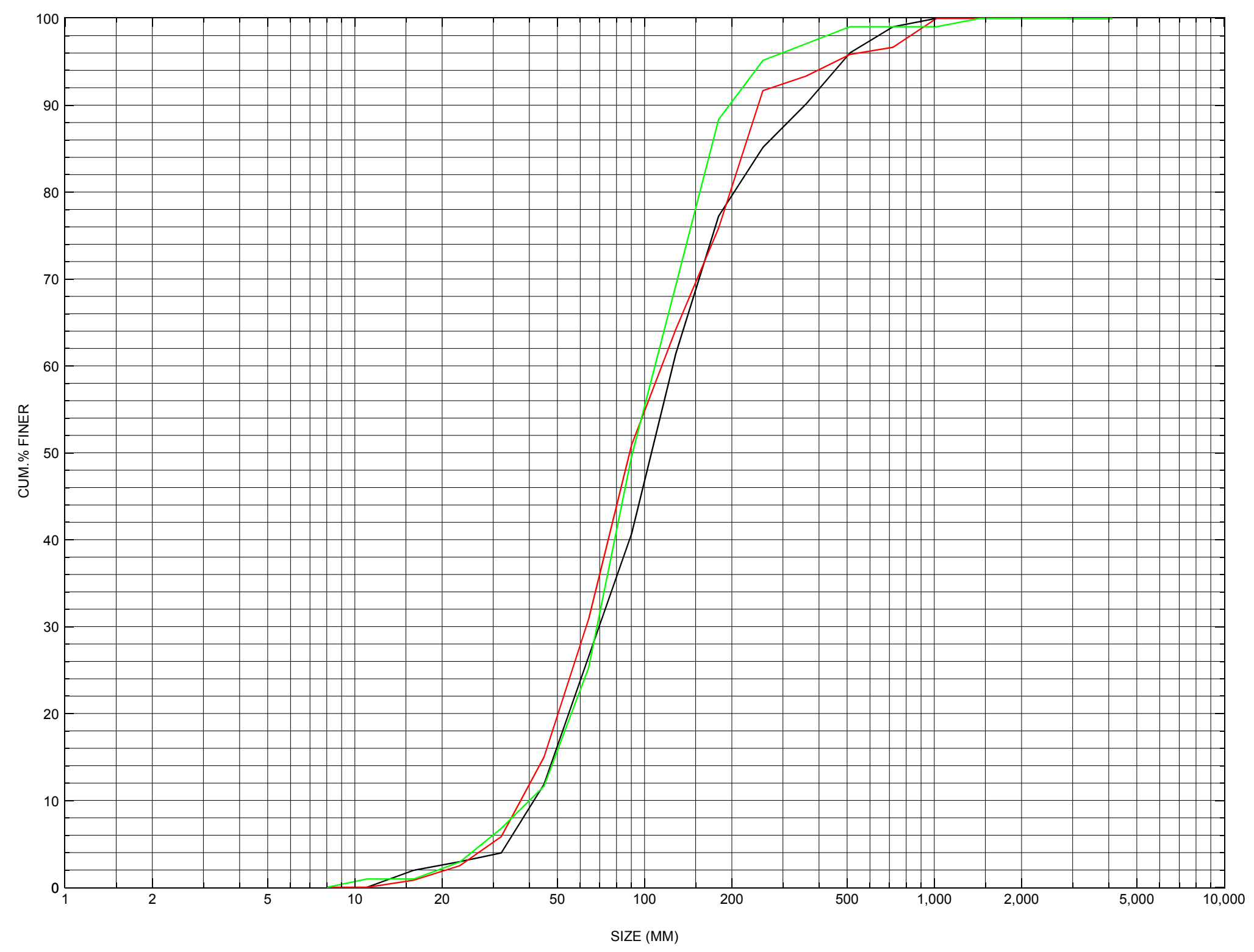

Appendix C. Bed material particle-size distributions for three pebble count transects at the approach cross-section for structure BARTTH00080037, in Barton, Vermont. 


\section{APPENDIX D: \\ HISTORICAL DATA FORM}




\section{Structure Number BARTTH00080037}

\section{General Location Descriptive}

Data collected by (First Initial, Full last name) M. WEBER

Date $(M M / D D / Y Y) \_\mathbf{0 8} / \underline{\mathbf{0 4}} / \underline{\mathbf{9 4}}$

Highway District Number $(I-2 ; n n) \underline{09}$

Town (FIPS place code; I - 4; nnnnn) $\mathbf{0 3 5 5 0}$

Waterway ( $(-6)$ WILLOUGHBY RIVER

Route Number TH08

Topographic Map Orleans

Latitude (I - 16; nnnn.n) $\mathbf{4 4 4 8 2}$
County (FIPS county code; I - 3; nnn)

Mile marker (I - 11; nnn.nnn) $\underline{000000}$

Road Name (I - 7): -

Vicinity (I - 9) 0.01 MI JCT TH 8 + VT 58

Hydrologic Unit Code: $\mathbf{0 1 1 1 0 0 0 0}$

Longitude (i - 17; nnnnn.n) $\mathbf{7 2 1 0 8}$

\section{Select Federal Inventory Codes}

FHWA Structure Number $(I-8) \quad 10100200371002$

Maintenance responsibility $(I-21 ; n n) \quad \mathbf{0 3}$

Year built (I - 27; YYYY) 1987

Average daily traffic, ADT (I - 29; nnnnnn) $\underline{000150}$

Year of ADT (I - 30; YY) $\mathbf{9 0}$

Opening skew to Roadway $(I-34 ; n n) \quad 12$

Operational status $(I-41 ; X) \quad \mathbf{A}$

Structure type (I - 43; nnn) $\mathbf{3 0 2}$

Approach span structure type $(I-44 ; n n n) \quad \mathbf{0 0 0}$

Number of spans (I - 45; nnn) 001

Number of approach spans (I - 46; nnnn) $\mathbf{0 0 0 0}$ Comments:

The structural inspection report of 7/18/92 indicates a single span steel stringer bridge. The abutments and wingwalls are like new. No noted channel scour. There is minor embankment erosion 100 feet upstream. A point bar has developed on the right abutment. The channel aligned straight through bridge. There is good stone fill coverage.
Maximum span length (I - 48; nnnn) $\underline{0094}$

Structure length (I - 49; nnnnnn) $\underline{\mathbf{0 0 0 0 9 6}}$

Deck Width (I - 52; nn.n) 254

Channel \& Protection $(I-61 ; n) \underline{7}$

Waterway adequacy $(I-71 ; n)$

Underwater Inspection Frequency (I - 92B; XYY) _ N

Year Reconstructed (I - 106) $\mathbf{0 0 0 0}$

Clear span (nnn.n ft) $\mathbf{0 9 0 . 0}$

Vertical clearance from streambed (nnn.n ft) $\underline{\mathbf{0 0 7 . 5}}$

Waterway of full opening $\left(n n n . n \mathrm{ft}^{2}\right) \quad \mathbf{6 7 5 . 0}$ 


\section{Bridge Hydrologic Data}

Is there hydrologic data available? $\underline{\mathbf{Y}}$ if No, type ctrl-n $h \quad$ VTAOT Drainage area $\left(\mathrm{mi}^{2}\right)^{2}: \underline{\mathbf{5 7 . 4}}$

Terrain character: Mountainous to hilly

Stream character \& type: -

Streambed material: Stone and gravel with random boulders

Discharge Data (cfs): $\quad \mathrm{Q}_{2.33}-$

$\mathrm{Q}_{50} \mathbf{3 1 5 0}$

Record flood date $(M M / D D / Y Y):-$

\begin{tabular}{ll}
$Q_{10} \frac{\mathbf{2 0 0 0}}{\mathbf{3 6 5 0}}$ & $Q_{25} \frac{\mathbf{2 6 5 0}}{\mathrm{Q}_{100}} \mathrm{Q}_{500}-$ \\
\hline
\end{tabular}

Water surface elevation $(f t):-$

Estimated Discharge (cfs): Velocity at $\mathrm{Q}$ $(\mathrm{ft} / \mathrm{s}):$

Ice conditions (Heavy, Moderate, Light) : - _ Debris (Heavy, Moderate, Light): Moderate

The stage increases to maximum highwater elevation (Rapidly, Not rapidly):

The stream response is (Flashy, Not flashy):

Describe any significant site conditions upstream or downstream that may influence the stream's stage: Abutment of old truss bridge is partially in stream on the upstream left bank.

Watershed storage area (in percent): _ _ \%

The watershed storage area is: - (1-mainly at the headwaters; 2- uniformly distributed; 3-immediatly upstream oi the site)

Water Surface Elevation Estimates for Existing Structure:

\begin{tabular}{|l|l|c|c|l|l|}
\hline Peak discharge frequency & $Q_{2.33}$ & $Q_{10}$ & $Q_{25}$ & $Q_{50}$ & $Q_{100}$ \\
Water surface elevation (ft)) & - & $\mathbf{7 9 9 . 1}$ & $\mathbf{7 9 9 . 7}$ & $\mathbf{8 0 0 . 3}$ & $\mathbf{8 0 0 . 7}$ \\
Velocity $(\mathrm{ft} / \mathrm{sec})$ & - & - & $\mathbf{1 0 . 6}$ & - & - \\
\hline
\end{tabular}

Long term stream bed changes: -

Is the roadway overtopped below the $\mathrm{Q}_{100}$ ? (Yes, No, Unknown): $\mathbf{U}$ Frequency: -

Relief Elevation (ft):

Discharge over roadway at $Q_{100}\left(f t^{3} / \mathrm{sec}\right)$ :

Are there other structures nearby? (Yes, No, Unknown): $\mathbf{Y}$ If No or Unknown, type ctrl-n os Upstream distance (miles): 1 Town: Brownington $\quad$ Year Built: 1928 Highway No. : TH 1 Structure No. : 9 Structure Type: Concrete T-beam Clear span (ft): 57 Clear Height $(f t):$ - $\quad$ Full Waterway $\left(f t^{2}\right):-$ 
Downstream distance (miles): $\underline{0.6}$ Town:

Highway No. : TH 3 Structure No. : 1 Structure Type: I-beam side girder

Clear span (ft): $\mathbf{5 0}$ Clear Height $(f t)$ : Full Waterway $\left(f^{2}\right)$ :

Comments:

\section{USGS Watershed Data}

Watershed Hydrographic Data

Drainage area $(D A) \quad \mathbf{6 0 . 3 9} \mathrm{mi}^{2}$ Lake and pond area

1.94 $\mathrm{mi}^{2}$

Watershed storage (ST) 3.2 $\%$

Bridge site elevation 807.4 $\mathrm{ft}$

Headwater elevation 2655.8 $\mathrm{ft}$

Main channel length $\mathbf{1 7 . 5 4}$ mi

$10 \%$ channel length elevation

885.8

$\mathrm{ft} \quad 85 \%$ channel length elevation

1169.6

Main channel slope

(S) $\mathrm{ft} / \mathrm{mi}$

Watershed Precipitation Data

Average site precipitation in

Average headwater precipitation in

Maximum 2yr-24hr precipitation event $(124,2)$ in

Average seasonal snowfall (Sn) $\mathrm{ft}$ 


\section{Bridge Plan Data}

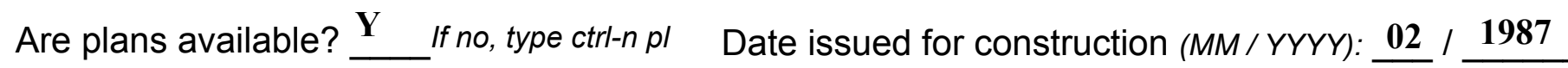
Project Number BRZ 1449(13)

Minimum channel bed elevation: $\mathbf{7 9 4 . 9}$

Low superstructure elevation: USLAB $\underline{\mathbf{8 0 2 . 2 5}}$ DSLAB $\underline{\mathbf{8 0 2 . 3 3}}$ USRAB $\underline{\mathbf{8 0 4 . 2 3}}$ DSRAB $\underline{\mathbf{8 0 4 . 3 1}}$ Benchmark location description:

BM \#1A, chiseled square in concrete head wall south east corner of square, located at middle of rightmost lane VT 58 north of bridge (downstream) elevation 800.94. BM \#1, chiseled square at top of north west corner of right abutment (downstream right abutment), elevation 806.79.

Reference Point (MSL, Arbitrary, Other): MSL Datum (NAD27, NAD83, Other):

Foundation Type: 1

If 1: Footing Thickness $\mathbf{2 . 0} \quad$ Footing bottom elevation: $\underline{\mathbf{7 9 5 . 0}}$

If 2: Pile Type:___ (1-Wood; 2-Steel or metal; 3-Concrete) Approximate pile driven length:

If 3: Footing bottom elevation:

Is boring information available? $\underline{\mathbf{Y}}$ If no, type ctrl- $n$ bi Number of borings taken: $\underline{4}$

Foundation Material Type: 1 (1-regolith, 2-bedrock, 3-unknown)

Briefly describe material at foundation bottom elevation or around piles:

Spreadfooting in mainly a silt material. Borings 3 and 4 show drilling into 10 and 11 feet of rock. Bedrock noted as a gray quartzose crystalline limestone (marble), at location of right abutment. Bedrock was not reached at the location of left abutment in borings 1 and 2.

Comments:

Some bridge plans in bridge record. Hydrologic data on plans: $Q 2.33=900$ elevation=797.5, $Q 10=2000$ at elevation $=799.1, Q 25=2650$ at elevation $=799.7, Q 50=3150$ at elevation $=800.3, Q 100=3650$ at elevation $=800.7$, velocity at $Q 25=10.6$ feet per second. 


\section{Cross-sectional Data}

Is cross-sectional data available? $\underline{\mathbf{Y}}$ If no, type ctrl-n xs

Source (FEMA, VTAOT, Other)? VTAOT

Comments: Cross-sections available.

\begin{tabular}{|l|l|l|l|l|l|l|l|l|l|l|l|}
\hline Station & & & & & & & & & & & \\
\hline Feature & & & & & & & & & & & \\
\hline $\begin{array}{l}\text { Low cord } \\
\text { elevation }\end{array}$ & & & & & & & & & & & \\
\hline $\begin{array}{l}\text { Bed } \\
\text { elevation }\end{array}$ & & & & & & & & & & & \\
\hline $\begin{array}{l}\text { Low cord to } \\
\text { bed length }\end{array}$ & & & & & & & & & & & \\
\hline Station & & & & & & & & & & & \\
\hline Feature & & & & & & & & & & & \\
\hline $\begin{array}{l}\text { Low cord } \\
\text { elevation }\end{array}$ & & & & & & & & & & & \\
\hline $\begin{array}{l}\text { Bed } \\
\text { elevation }\end{array}$ & & & & & & & & & & & \\
\hline $\begin{array}{l}\text { Low cord to } \\
\text { bed length }\end{array}$ & & & & & & & & & & & \\
\hline
\end{tabular}

Source (FEMA, VTAOT, Other)?

Comments:

\begin{tabular}{|l|l|l|l|l|l|l|l|l|l|l|l|}
\hline Station & & & & & & & & & & & \\
\hline Feature & & & & & & & & & & & \\
\hline $\begin{array}{l}\text { Low cord } \\
\text { elevation }\end{array}$ & & & & & & & & & & & \\
\hline $\begin{array}{l}\text { Bed } \\
\text { elevation }\end{array}$ & & & & & & & & & & & \\
\hline $\begin{array}{l}\text { Low cord to } \\
\text { bed length }\end{array}$ & & & & & & & & & & & \\
\hline Station & & & & & & & & & & & \\
\hline Feature & & & & & & & & & & & \\
\hline $\begin{array}{l}\text { Low cord } \\
\text { elevation }\end{array}$ & & & & & & & & & & & \\
\hline $\begin{array}{l}\text { Bed } \\
\text { elevation }\end{array}$ & & & & & & & & & & & \\
\hline $\begin{array}{l}\text { Low cord to } \\
\text { bed length }\end{array}$ & & & & & & & & & & & \\
\hline
\end{tabular}




\section{APPENDIX E: \\ LEVEL I DATA FORM}


U. S. Geological Survey

Bridge Field Data Collection and Processing Form

Qa/Qc Check by: MAI Date: $1 / \mathbf{2 6 / 9 5}$

SimENT OF

\section{A. General Location Descriptive}

1. Data collected by (First Initial, Full last name) E. BOEHMLER

Date $(M M / D D / Y Y)$

$10 / 20$

/ 1994

2. Highway District Number 09

County ORLEANS (019)

Waterway (I - 6) WILLOUGHBY RIVER

Route Number TH08

3. Descriptive comments:

The structure is a steel stringer type bridge located about 20 feet from the intersection of TH08 with state route 58.

\section{B. Bridge Deck Observations}
4. Surface cover... LBUS 2
RBUS 6
LBDS 2
RBDS 4
Overall 2

(2b us,ds,lb,rb: 1- Urban; 2- Suburban; 3- Row crops; 4- Pasture; 5- Shrub- and brushland; 6- Forest; 7- Wetland)
5. Ambient water surface... US $\underline{2}$
UB 2
DS $\underline{2}$
(1- pool; 2- riffle)

6. Bridge structure type 1 (1- single span; 2- multiple span; 3- single arch; 4- multiple arch; 5-cylindrical culvert; 6- box culvert; or 7- other)
7. Bridge length $\mathbf{9 6 . 0}$
(feet)
Span length $\mathbf{9 4 . 0}$
(feet)
Bridge width 25.4 (feet)

\section{Road approach to bridge:}
8. LB 0
RB 0
( 0 even, 1- lower, 2- higher)
9. LB_
$\mathrm{RB} \underline{1}$
(1- Paved, 2- Not paved)

10. Embankment slope (run / rise in feet / foot):

US left -:1

US right $\quad \mathbf{6 . 6 : 1}$

\begin{tabular}{|c|c|c|c|c|}
\hline & \multicolumn{2}{|c|}{ Protection } & \multirow{2}{*}{ 13.Erosion } & \multirow{2}{*}{ 14.Severity } \\
\hline & 11.Type & 12.Cond. & & \\
\hline LBUS & $\mathbf{0}$ & - & 2 & 1 \\
\hline RBUS & $\mathbf{0}$ & - & 2 & 1 \\
\hline RBDS & 0 & - & 2 & 2 \\
\hline LBDS & $\mathbf{0}$ & - & $\mathbf{0}$ & $\mathbf{0}$ \\
\hline
\end{tabular}

Bank protection types: 0- none; 1- < 12 inches;

2- < 36 inches; $3-<48$ inches;

4- $<60$ inches; 5- wall / artificial levee

Bank protection conditions: 1- good; 2- slumped;

3- eroded; 4- failed

Erosion: 0 - none; 1- channel erosion; 2-

road wash; 3- both; 4- other

Erosion Severity: 0 - none; 1- slight; 2- moderate;

\section{Channel approach to bridge (BF):}

15. Angle of approach: $\mathbf{0}$

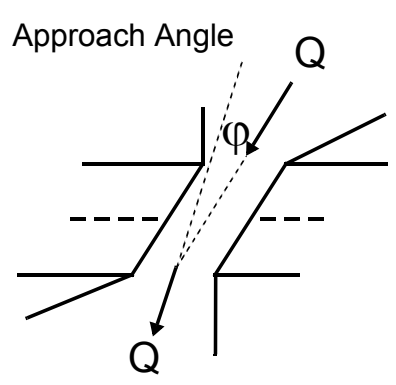

17. Channel impact zone 1 :

Where? LB $(L B, R B)$

Range? 155 feet US

Channel impact zone 2:

Where? LB (LB, RB)

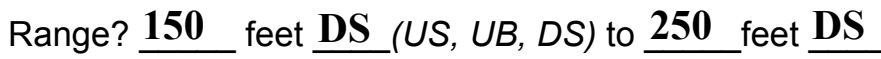

Impact Severity: 0- none to very slight; 1- Slight; 2- Moderate; 3- Severe
16. Bridge skew: 15

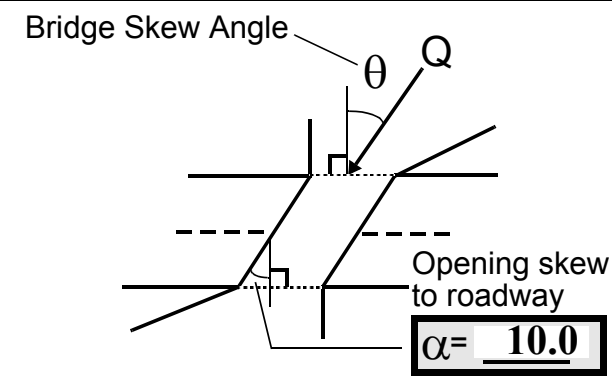

\section{Exist? $\mathbf{Y}(Y$ or $N)$}

Severity 1

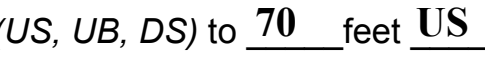

Exist? $\mathbf{Y}(Y$ or $N)$

Severity 1 
18. Level II Bridge Type: $\underline{\mathbf{1 A} / \mathbf{4}}$

1a- Vertical abutments with wingwalls

$1 \mathrm{~b}$ - Vertical abutments without wingwalls

2- Vertical abutments and wingwalls, sloping embankment

Wingwalls perpendicular to abut. face

3- Spill through abutments

4- Sloping embankment, vertical wingwalls and abutments

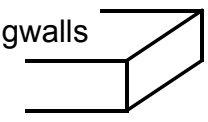

1a with wingwalls

Wingwall angle less than $90^{\circ}$.

19. Bridge Deck Comments (surface cover variations, measured bridge and span lengths, bridge type variations,

approach overflow width, etc.)

Upstream and downstream left bank coverage is mainly the roadway and homes except at the immediate channel edge where some trees and brush are present. Coverage on the downstream right bank is mainly pasture during the off season but may have row crops during the summer months. The right bank downstream coverage is all forested except for brush on a narrow land area just adjacent to the channel. Measured bridge dimensions were, 1) bridge length $=96.0$ feet, span length $=94.0$ feet, and roadway width $=\mathbf{2 5 . 0}$ feet.

\section{Upstream Channel Assessment}

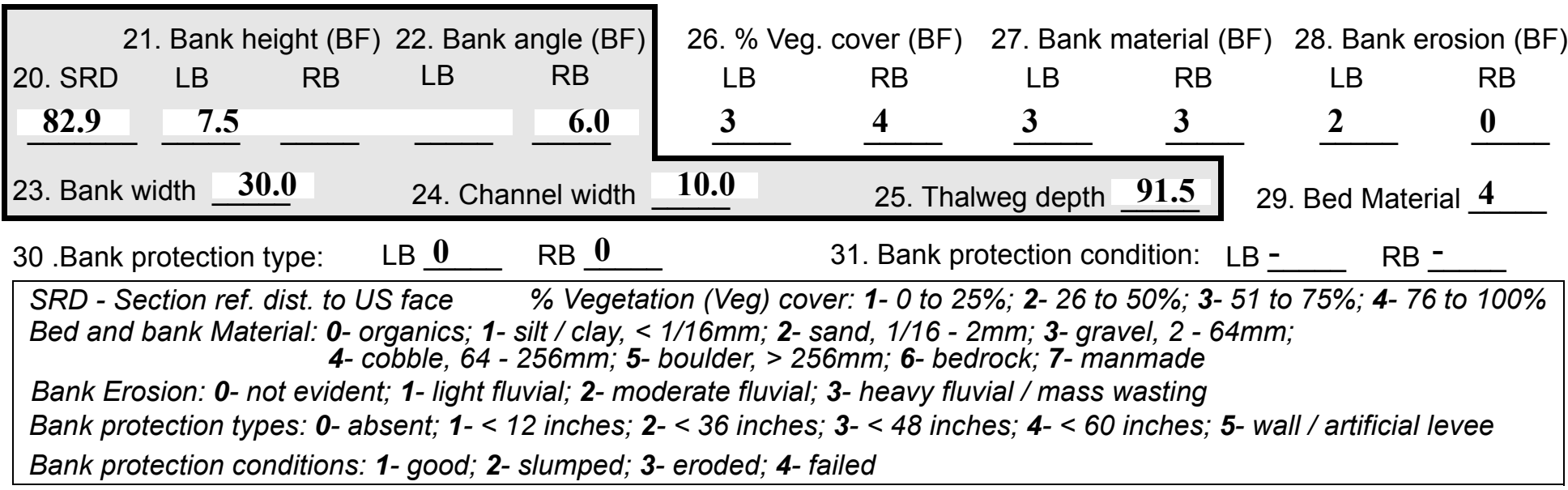

32. Comments (bank material variation, minor inflows, protection extent, etc.):

The bank material is mainly fine to coarse gravel and sand with a few boulders. The bed material is boulder and cobble size mainly in a fine to coarse sand and fine gravel. For the most part, the banks are unprotected. An old abutment remains on the left bank upstream which provides bank protection in the area from the bridge to about 40 feet upstream. There was no protection further upstream from the old left abutment. Some class 2 (cut stone) riprap protects the upstream right bank mainly from roadwash but sits back about 40 feet from the channel. 
36. Point bar extent: $\underline{\mathbf{3 2 5}}$ feet $\underline{\mathrm{US}}$ (US, UB) to $\underline{\mathbf{1 5 0}}$ feet DS (US, UB, DS) positioned $\underline{\mathbf{8 5}} \%$ LB to $100 \% \mathrm{RB}$

37. Material: 4

38. Point or side bar comments (Circle Point or Side; Note additional bars, material variation, status, etc.):

The point bar is composed of cobbles and boulder size material with some coarse gravel and fine to coarse sand. It does not appear active as brush and shrubs are growing on it. The point bar is inconspicuous somewhat due to the growth on it but extends along the inside of a long, slight channel bend. Local sources indicate the point bar area is submerged nearly every year during spring runoff.
39. Is a cut-bank present? Y
( $Y$ or if $N$ type $c$ trl-n $c b)$
40. Where? LB (LB or RB)
40. Where? $\mathrm{LB}$ (LB or RB)

41. Mid-bank distance: $\mathbf{2 1 0}$

42. Cut bank extent 350

43. Bank damage: 2

(1- eroded and/or creep; 2 - slip failure; 3- block failure)

44. Cut bank comments (eg. additional cut banks, protection condition, etc.):

No protection is present at the cut bank location. Some native cobble and boulder bank material that remains has formed a shallower slope from the toe of the bank to roughly one half the bank height.

\section{Is channel scour present? $\mathbf{N}$ ( $Y$ or if $N$ type ctrl-n $c s$ )}

47. Scour dimensions: Length Width -

Depth : -

46. Mid-scour distance: -

48. Scour comments (eg. additional scour areas, local scouring process, etc.):

NO CHANNEL SCOUR

49. Are there major confluences? $\mathbf{Y}$ ( $Y$ or if $N$ type ctrl-n $m c$ )

51. Confluence 1: Distance $\mathbf{2 0 0}$

Confluence 2: Distance ( $L B$ or $R B)$

52. Enters on $\underline{\mathbf{L B}}$

Enters on (LB or $R B)$
50. How many? 1

53. Type 1 (1- perennial; 2- ephemeral)
Type - (1- perennial; 2- ephemeral)

54. Confluence comments (eg. confluence name):

The tributary is perennial but not named.

\section{Under Bridge Channel Assessment}

55. Channel restraint (BF)? LB 2

\begin{tabular}{|ccccc}
\hline \multicolumn{2}{|c}{56. Height (BF) } & \multicolumn{3}{c}{57 Angle (BF) } \\
LB & RB & LB & RB \\
$\mathbf{4 6 . 5}$ & & & $\mathbf{1 . 0}$ & \\
\hline
\end{tabular}
(1- natural bank; 2- abutment; 3- artificial levee)

58. Bank width (BF) -

59. Channel width (Amb) -

61. Material (BF)

LB RB

$\underline{2} \quad \underline{7}$
62. Erosion (BF)

LB RB

$7 \quad \mathbf{0}$

Bed and bank Material: 0- organics; 1- silt / clay, < 1/16mm; 2- sand, 1/16 - 2mm; 3- gravel, 2 - 64mm; 4- cobble, 64 - 256mm; 5- boulder, > 256mm; 6- bedrock; 7- manmade

Bank Erosion: 0- not evident; 1- light fluvial; 2- moderate fluvial; 3- heavy fluvial / mass wasting

64. Comments (bank material variation, minor inflows, protection extent, etc.):

3

The point bar indicated on the right bank upstream continues under the bridge to about 50 feet downstream and might be considered a natural bank under the bridge. The point bar (natural bank) material under the bridge is fine to medium sand, coarse gravel and a few boulders with no evident erosion. The under bridge bed material on the surface is a coarse gravel with some cobbles and a few scattered boulders. 
65. Debris and Ice Is there debris accumulation?

$(Y$ or $N)$ 66. Where? $\mathbf{N}$

(1- Upstream; 2- At bridge; 3- Both)

67. Debris Potential ( 1- Low; 2- Moderate; 3- High)

68. Capture Efficiency 2

(1-Low; 2- Moderate; 3- High)

69. Is there evidence of ice build-up? 1 (Y or $N)$

Ice Blockage Potential $\mathbf{N}$

(1- Low; 2- Moderate; 3- High)

70. Debris and Ice Comments:

1

A local source noted periods of ice flows with water levels high enough such that blocks of ice loudly hit the steel I-beams. Ice blocks are frequently deposited in the field on the right overbank downstream. Trees are undermined on banks and some are leaning (horizontal) on the right bank upstream. Hence, the potential for debris production is probably moderate.

\begin{tabular}{|l|c|c|c|c|c|c|c|c|}
\hline Abutments & $\begin{array}{c}\text { 71. Attack } \\
\angle \mathrm{BF})\end{array}$ & $\begin{array}{c}\text { 72. Slope } \\
(\mathrm{Qmax})\end{array}$ & $\begin{array}{c}\text { 73. Toe } \\
\text { loc. (BF) }\end{array}$ & $\begin{array}{c}\text { 74. Scour } \\
\text { Condition }\end{array}$ & $\begin{array}{c}\text { 75. Scour } \\
\text { depth }\end{array}$ & $\begin{array}{c}\text { 76. Exposure } \\
\text { depth }\end{array}$ & 77. Material & 78. Length \\
\hline LABUT & & $\mathbf{0}$ & $\mathbf{9 0}$ & $\mathbf{2}$ & $\mathbf{0}$ & - & - & $\mathbf{9 0 . 0}$ \\
\hline RABUT & $\mathbf{1}$ & $\mathbf{0}$ & $\mathbf{9 0}$ & & & $\mathbf{0}$ & $\mathbf{0}$ & $\mathbf{9 1 . 0}$ \\
\hline
\end{tabular}

Pushed: $L B$ or RB

Toe Location (Loc.): 0- even, 1- set back, 2- protrudes

Scour cond.: 0- not evident; 1- evident (comment); 2- footing exposed; 3-undermined footing; 4- piling exposed; 5- settled; 6- failed

Materials: 1- Concrete; 2- Stone masonry or drywall; 3- steel or metal; 4- wood

79. Abutment comments (eg. undermined penetration, unusual scour processes, debris, etc.):

$-$

1

The abutments are in good condition.

80. Wingwalls:

Exist? Material? Scour Scour Exposure Angle? Length? Condition? depth? depth?

USLWW:

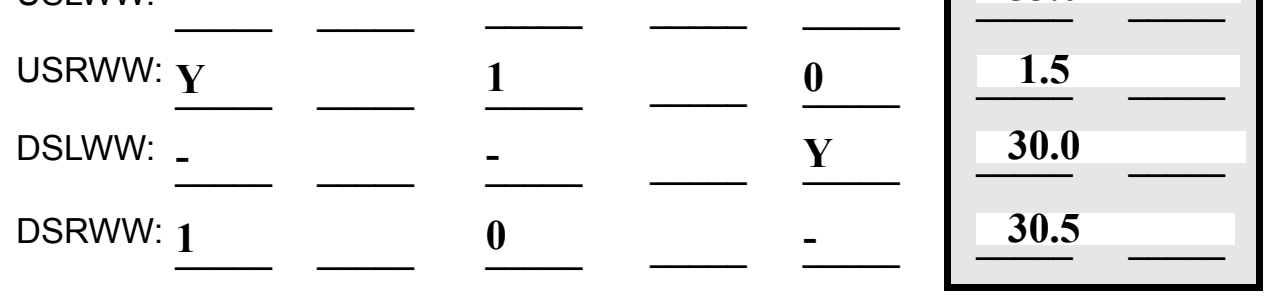

Wingwall materials: 1- Concrete; 2- Stone masonry or drywall; 3- steel or metal; 4- wood

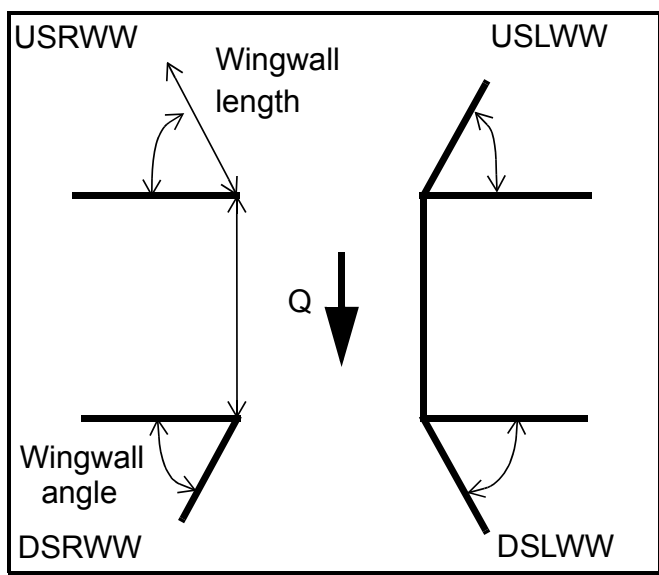

82. Bank / Bridge Protection:

\begin{tabular}{|l|l|l|l|l|l|l|l|l|}
\hline Location & USLWW & USRWW & LABUT & RABUT & LB & RB & DSLWW & DSRWW \\
\hline Type & - & $\mathbf{0}$ & $\mathbf{Y}$ & - & $\mathbf{1}$ & $\mathbf{1}$ & $\mathbf{1}$ & $\mathbf{1}$ \\
\hline Condition & $\mathbf{Y}$ & - & $\mathbf{1}$ & - & $\mathbf{1}$ & $\mathbf{1}$ & $\mathbf{1}$ & $\mathbf{1}$ \\
\hline Extent & $\mathbf{1}$ & - & $\mathbf{0}$ & $\mathbf{2}$ & $\mathbf{2}$ & $\mathbf{2}$ & $\mathbf{2}$ & - \\
\hline
\end{tabular}

Bank / Bridge protection types: 0- absent; 1- < 12 inches; 2- < 36 inches; 3- < 48 inches; 4- < 60 inches; 
83. Wingwall and protection comments (eg. undermined penetration, unusual scour processes, etc.):

-
-
-
-
-
2
1
1
2
1
1

Piers:

84. Are there piers? Th (Y or if N type ctrl-n pr)

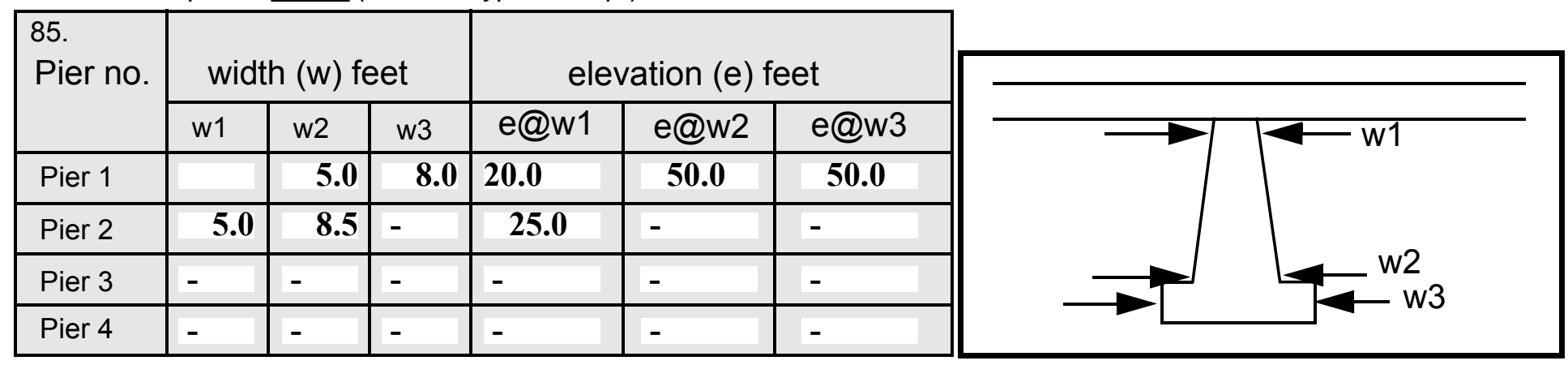

\begin{tabular}{|l|l|l|l|l|}
\hline Level 1 Pier Descr. & \multicolumn{1}{|c|}{1} & \multicolumn{1}{|c|}{2} & \multicolumn{1}{|c|}{3} & \multicolumn{1}{|c|}{} \\
\hline 86. Location (BF) & e & dow & ng & de- \\
\hline 87. Type & pro- & nstre & out & vel- \\
\hline 88. Material & tec- & am & from & oped \\
\hline 89. Shape & tion & right & area & a \\
\hline 90. Inclined? & foun & wing & due & gul- \\
\hline 91. Attack $\angle$ (BF) & d at & wall & to & ly \\
\hline 92. Pushed & the & is & road & be- \\
\hline 93. Length (feet) & - & - & - & - \\
\hline 94. \# of piles & ex- & slum & wash & hind \\
\hline 95. Cross-members & trem & ping & - & the \\
\hline 96. Scour Condition & e end & and/ & Ero- & wing \\
\hline 97. Scour depth & of & or & sion & wall. \\
\hline 98. Exposure depth & the & erodi & has & The \\
\hline
\end{tabular}

LFP, LTB, LB, MCL, MCM, MCR, RB, RTB, RFP

1- Solid pier, 2-column, 3- bent

1-Wood; 2-concrete; 3- metal; 4- stone

1- Round; 2- Square; 3- Pointed

Y-yes; $N$ - no

$L B$ or $R B$

0- none; 1- laterals; 2- diagonals; 3- both

0- not evident; 1- evident (comment);

2- footing exposed; 3- piling exposed;

4- undermined footing; 5- settled; 6- failed 
99. Pier comments (eg. undermined penetration, protection and protection extent, unusual scour processes, etc.): abutment protection forms a 35 to 40 degree slope from the toe to the concrete walls and sits up high covering nearly two thirds of each abutment's face.

$\mathbf{N}$

100.

\section{E. Downstream Channel Assessment}

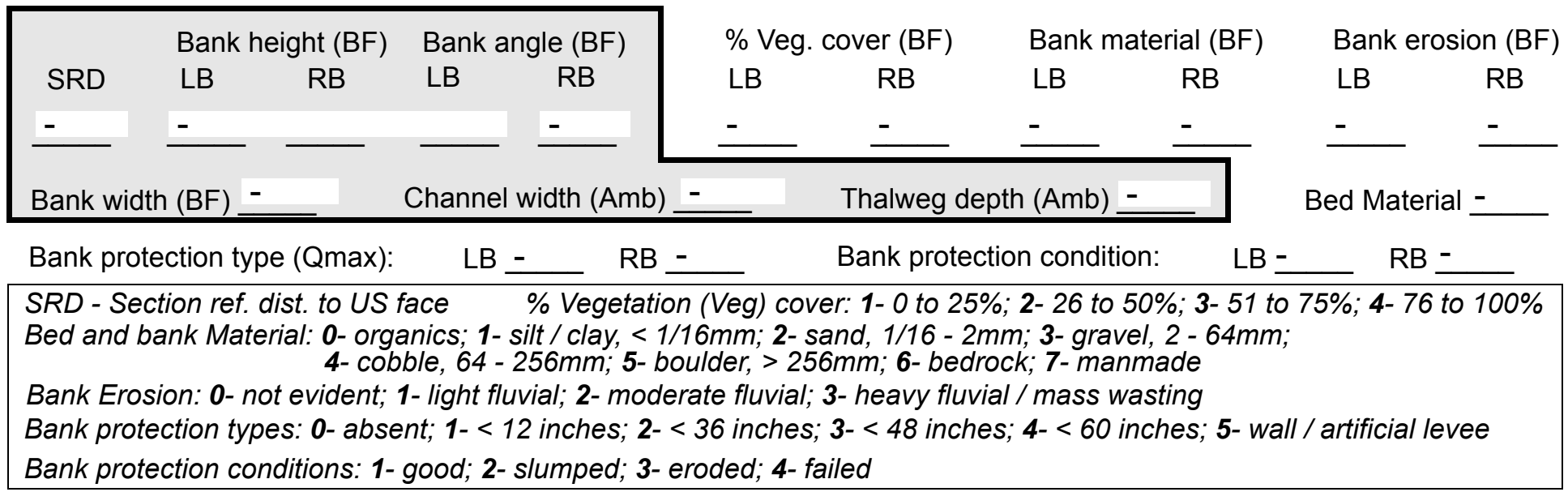

Comments (eg. bank material variation, minor inflows, protection extent, etc.):

-

$-$

$-$

$-$

$-$

$-$

$-$

$-$

$-$

$-$

$-$

$-$

$-$

$-$

$-$

101. Is a drop structure present? _ ( $Y$ or $N$, if $N$ type ctrl-n ds) 102. Distance: ___ feet
103. Drop: - feet
104. Structure material: -
(1- steel sheet pile; 2- wood pile; 3- concrete; 4- other)

105. Drop structure comments (eg. downstream scour depth):

$-$

$-$

$-$

- 
106. Point/Side bar present? (Y or $N$. if $N$ type ctrl-n pb)Mid-bar distance:

Mid-bar width: -

Point bar extent: feet -

(US, UB, DS) to feet (US, UB, DS) positioned $\%$ LB to $\% \mathrm{RB}$ Material:

Point or side bar comments (Circle Point or Side; note additional bars, material variation, status, etc.):

S a cut-bank present? $\mathbf{N}$ (Y or if $N$ type ctrl-n cb) Where? $\underline{\mathbf{O}}$ (LB or RB) Mid-bank distance: PIE Cut bank extent: $\underline{\mathbf{R S}}$ feet __ (US, UB, DS) to feet __ (US, UB, DS)

Bank damage: (1- eroded and/or creep; 2- slip failure; 3- block failure)

Cut bank comments (eg. additional cut banks, protection condition, etc.):

Is channel scour present? ( $Y$ or if $N$ type ctrl-n cs) Width 4 Depth: 4 Mid-scour distance: $\underline{2}$ Scour dimensions: Length $\underline{3}$

Scour comments (eg. additional scour areas, local scouring process, etc.): 5

0

$\mathbf{0}$

Are there major confluences? Confluence 1: Distance sion Confluence 2: Distance cur( $Y$ or if $N$ type ctrl-n $m c)$ Positioned 1 $\%$ LB to 1 $\% \mathrm{RB}$ Confluence comments (eg. confluence name):

htly on the right bank and at the upstream end of the point bar on left bank in the impact zone downstream.

\section{F. Geomorphic Channel Assessment}

107. Stage of reach evolution
How many? Ero-

Type oc(1- perennial; 2- ephemeral) Type slig (1- perennial; 2- ephemeral) Enters on ring ( $L B$ or $R B$ )

1- Constructed

2- Stable

3- Aggraded

4- Degraded

5- Laterally unstable

6- Vertically and laterally unstable 
108. Evolution comments (Channel evolution not considering bridge effects; See HEC-20, Figure 1 for geomorphic descriptors): 


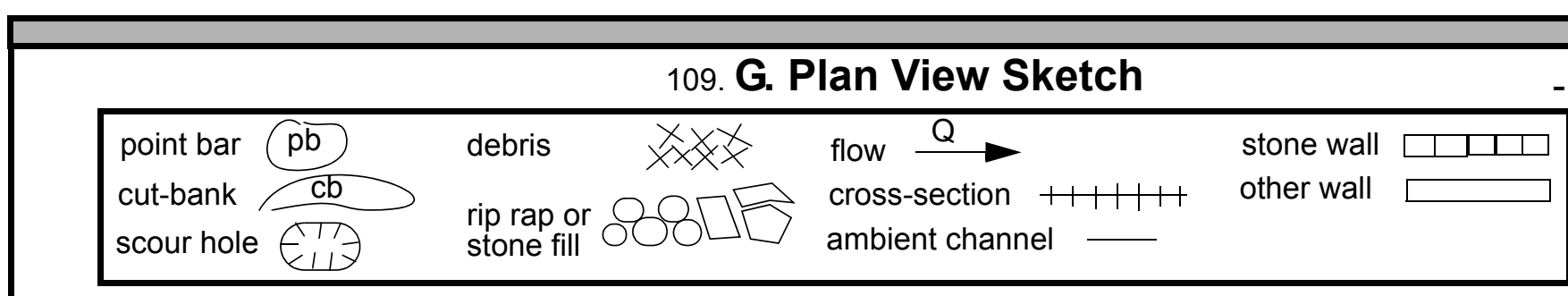


APPENDIX F:

SCOUR COMPUTATIONS 
SCOUR COMPUTATIONS

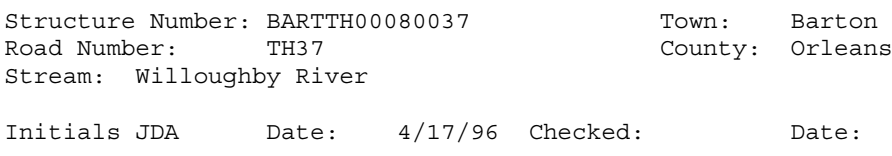

Results

Live-bed(1) or Clear-Water(0) Contraction Scour?

Main Channel

Left Overbank

Right Overbank 
Clear Water Contraction Scour in MAIN CHANNEL

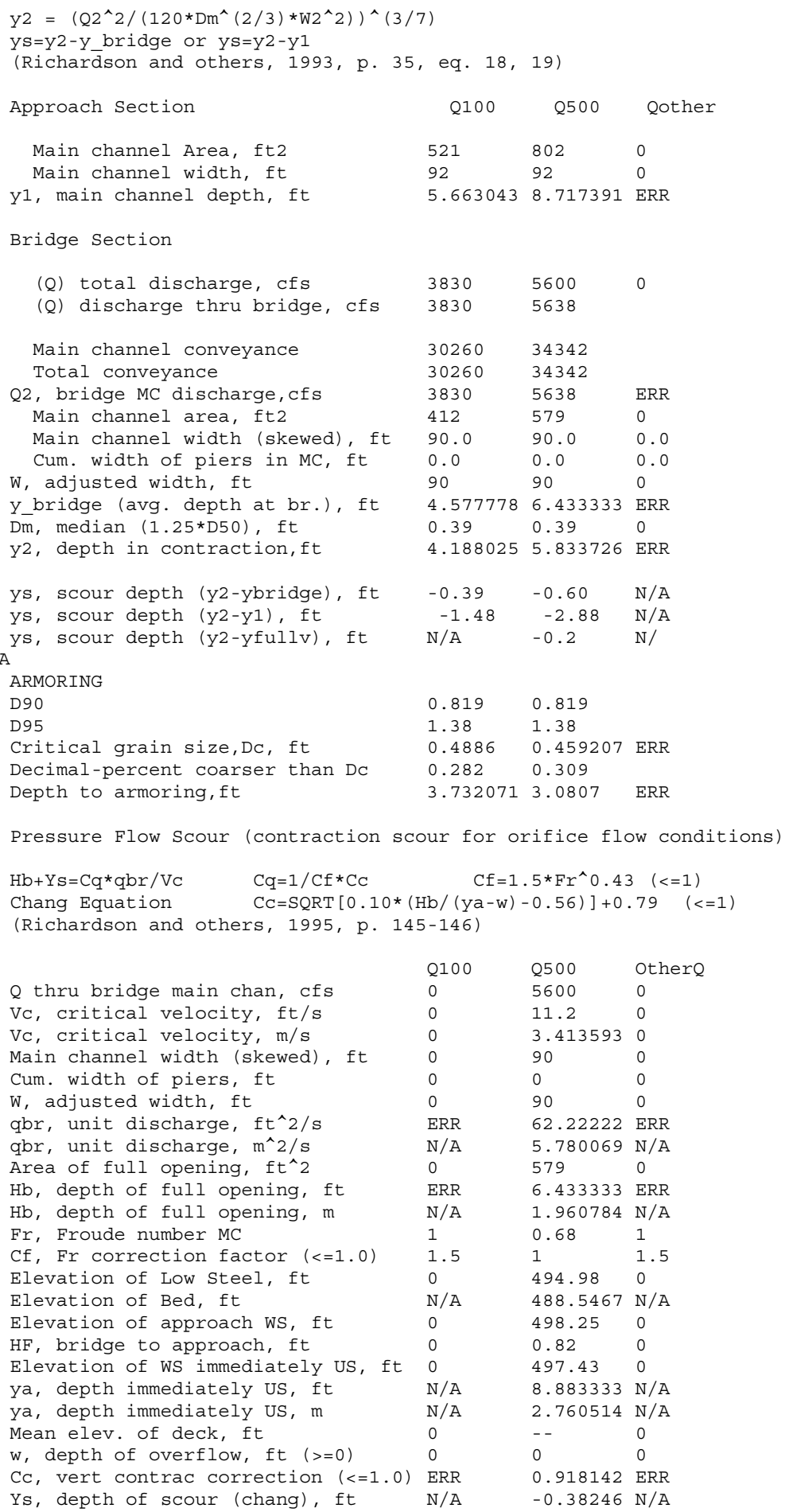




$\begin{array}{lllllll}\text { Fr>0.8 (vertical abut.) } & \text { ERR } & \text { ERR } & \text { ERR } & \text { ERR } & \text { ERR } & \text { ERR }\end{array}$

